\title{
Success and failure in marketing strategy making: Results of an empirical study across medical markets
}

Received: 27th May, 2003

\section{Brian Smith}

is the Managing Consultant of PragMedic, a consultancy which supports business planning in medical markets, and obtained his PhD from Cranfield University School of Management. He is also Managing Editor of the International Journal of Medical Marketing.

\section{Keywords marketing strategy, strategy process, medical}

Abstract This is the second in a trilogy of papers reporting on a five-year research project into marketing strategy making in medical markets. Following on from the weak marketing strategy observed in the first paper, this work explains the origins of marketing strategy process failure in terms of incongruence with market and organisational culture conditions. It concludes that any generic approach to marketing strategy making fails most companies, and that an organisationally tailored process is required.

\section{INTRODUCTION}

This is the second paper of a trilogy which seeks to contribute to the improvement of marketing strategy making in medical markets. For the purposes of this work, medical markets are defined as those markets in which the customer is a clinician or related professional or an associated organisation. It therefore includes pharmaceuticals, medical devices, diagnostics, medical equipment and other areas. This trilogy of papers arises from a five-year research project aimed specifically at this area and involving many leading companies in the sector. Although complementary and to some extent overlapping, the three papers attempt to answer three distinct questions, the relevance of which is emphasised by the maturation of the medical market:

PragMedic, 8 Canonsfield Road, Welwyn, Hertfordshire, AL6 OQH.

Tel: + 44 (0)1438 712441 ; Fax: + 44 (0)1438 712 442; e-mail: PragMedic@aol.com
- How good is marketing strategy in medical markets? Paper one presented an assessment of marketing strategy quality in medical markets against a set of contextindependent quality criteria derived from the literature. Its conclusions were that marketing strategy in the sector was of variable quality and often very weak.

- Why is marketing strategy in medical markets of variable quality? Paper two considers the underlying reasons for variability in the quality of marketing strategy in medical markets and develops and justifies a model to explain that variability.

- How might marketing strategy in medical markets be improved? Paper three develops the empirical work into a management process by which to improve marketing strategy making in medical markets and to test the outputs of that process prior to incurring the costs and risks of implementation.

Given the weaknesses of marketing strategy observed in medical markets, reported in the first paper, this work attempts to develop a model to explain the variability in quality of marketing strategy 
in medical markets. In particular this work seeks to understand the nature of process failure in marketing strategy making in medical markets. Its findings arise from a five-year study into the sector carried out as a $\mathrm{PhD}$ under Cranfield School of Management in the UK.

\section{THE EFFECTIVENESS OF MARKETING STRATEGY MAKING PROCESSES}

\section{A definition of marketing strategy}

'Marketing strategy' has the dubious honour of being one of the most abused terms in the lexicon of practitioners. Most frequently, it is used to refer to the tactical disposition of promotional resources. This work, however, uses the term 'marketing strategy' in the sense agreed by Drucker ${ }^{2}$ and Mintzberg. ${ }^{3}$ Hence, marketing strategy is that sustained pattern of resource allocation decisions that pertain to customers and propositions. In this sense, marketing strategy is defined as having two necessary components: a definition of the target 'market', and a statement of the 'product' or 'value proposition' aimed at that target. This dual-component view of marketing strategy is sufficient to differentiate marketing strategy from strategies relating to other, non-marketing functions, such as research and development or manufacturing, and from other non-strategy aspects of marketing management, such as tactical actions.

In the first paper of this trilogy, the extant literature was used to develop a context-independent set of properties by which the quality of marketing strategy might be measured. Using these properties as a benchmark, it was observed that the marketing strategy of many medical companies was weak, particularly in respect of target market definition, proposition tailoring, SWOT (strengths, weaknesses, opportunities and threats) alignment and strategy uniqueness. It was these findings that led to the investigation of why such process failure occurs and what factors influence the effectiveness of marketing-strategy-making processes.

\section{The hybrid nature of marketing strategy making processes}

Although marketing strategy making is often misleadingly referred to as 'marketing planning', the strategy process literature shows that rational planning is in fact only one component of a complex hybrid process by which organisations create marketing strategy. Much of the strategy process literature, in both strategic marketing planning and the broader strategic management field, reflects the singular perspectives of individual researchers on strategy development. This single-perspective literature argues for the consideration of strategy development as, for instance, a rational, planned process or an incremental process. An admirable summary of this work is contained in the work of Bailey et al.; ${ }^{4}$ the key dimensions of strategy development were identified as:

- Command: strategy deriving mainly from a key individual or top management team..$^{5-8}$

- Planning: strategy deriving mainly from a logical, sequential, deliberate set of procedures. $^{9-13}$

- Incremental: strategy deriving mainly from 'successive limited comparisons of alternative actions' ${ }^{14-17}$

- Political: strategy deriving mainly from negotiated settlements between powerful sub-units of the organisation. ${ }^{18-22}$

- Cultural: strategy deriving mainly from the 'taken for granted' frames of reference shared in the organisation. ${ }^{23-26}$

- Enforced choice: strategies deriving mainly from the external forces and constraints acting on the organisation. ${ }^{27-29}$

These single-perspective schools of thought are also considered by Mintzberg, ${ }^{30}$ who perceived strategy process as essentially a hybrid process and rationalised the singleperspective views as not incorrect but 
simply one perspective on a very complex phenomenon. To quote Mintzberg ( $\mathrm{p}$. 372):

'Strategy formation is judgmental designing, intuitive visioning and emergent learning'

Mintzberg's work suggests that such single-perspective studies clearly elucidate the contribution that each dimension, such as planning or incrementalism, makes to strategy development. In doing so, however, they understate the complex nature of the multiple simultaneous processes that constitute strategy making in practice.

Building on single-perspective schools, other attempts to identify typologies or taxonomies of strategy-development processes in practice reflect a multipleperspective view of these processes. These show an evolution in sophistication based upon recognising and incorporating the various schools of thought. Hence there are structures suggesting three, ${ }^{31}$ four, ${ }^{32,33}$ five, ${ }^{34,35}$ and six, ${ }^{36}$ modes of strategy development. Each of these pieces of work identifies a number of typologies of strategy development, each of which can be seen as hybrids, containing a blend of the single-perspective dimensions in varying ratios. While differing in terminology and complexity, this stream of research presents a coherent theme of strategy making as a hybrid process. These attempts to identify a taxonomy of strategy development processes are summarised below:

- linear, adaptive, interpretative ${ }^{37}$

- managerial autocracy, systemic bureaucracy, adaptive planning, political expediency $^{38}$

- rational, transactional, symbolic, generative $^{39}$

- command, rational, transactional, symbolic, generative $^{40}$

- commander, change, collaborative, cultural, crescive ${ }^{41}$

- planning, logical incremental, planning command, muddling through, externally dependent, political cultural command. ${ }^{42}$

This evolution of academic thought indicates that strategy making is

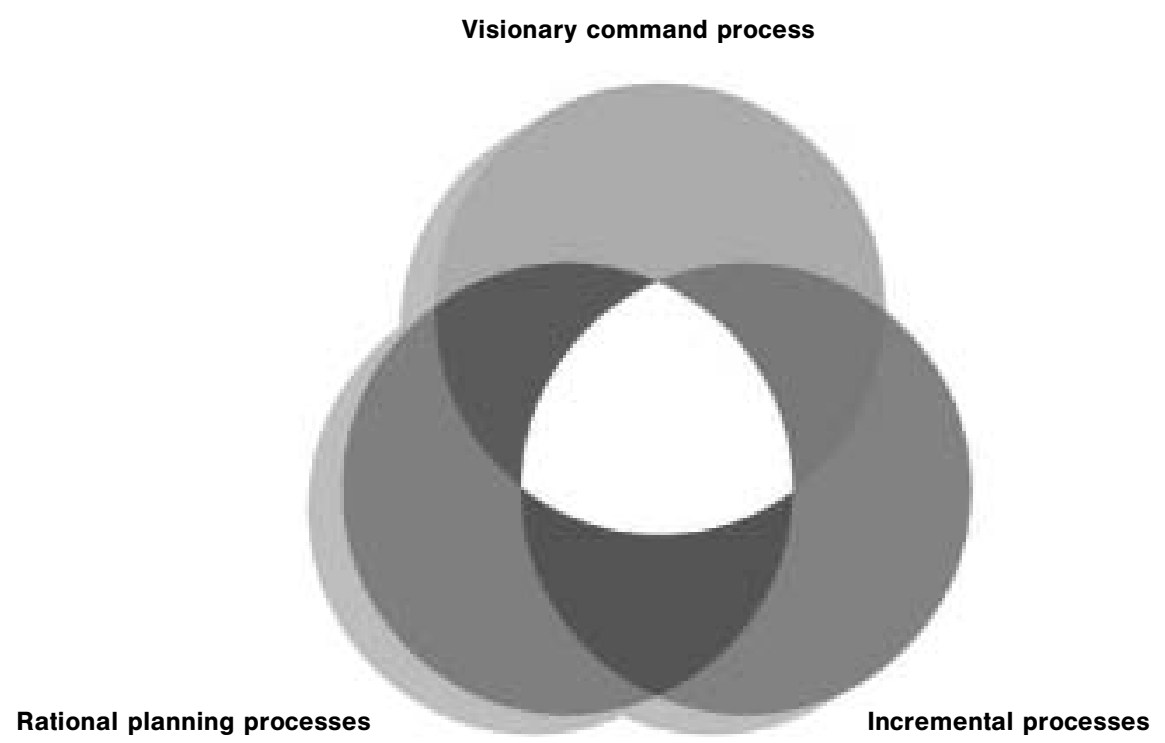

Figure 1: The three contributing processes of marketing strategy making Source: McDonald (1996) 
complex, involving multiple processes. Further, it suggests that each organisation, although broadly complying with one or other typology of strategy making process, has a unique process consisting of a singular combination of the various influences that go to make up the overall process.

While much of the strategy process literature relates to strategy making in general, a helpfully rationalised model of this hybrid strategy making process has been proposed for strategic marketing planning in particular. ${ }^{43}$ This model (see Figure 1) envisages the development of marketing strategy as a blend of rational planning, visionary and incremental processes, analogous to the manner in which the three primary colours mix.

Hence the strategy process literature suggests that any attempt to understand the effectiveness of marketing strategy making processes must consider the hybrid composition of the process employed. Comparison of hybrid marketing strategy making process type to the properties of the resultant strategy might provide a better explanation of the effectiveness of marketing strategy making processes than measurement of any one dimension, such as planning. Such an explanation is still likely to be incomplete, however, incorporating as it does only the process and its outputs. A more valuable understanding is likely to include the context in which the process functions to create the strategy.

\section{FACTORS AFFECTING THE EFFECTIVENESS OF MARKETING STRATEGY MAKING PROCESSES}

\section{Mediators of marketing strategy making process effectiveness}

The published work in this area falls broadly into three categories:
- the extent to which strategic marketing planning is used

- the internal (organisational) mediators of marketing-strategy-making processes

- the external (market) mediators of marketing-strategy-making processes.

The following sections attempt to critically assess the literature in each of those areas.

\section{The observed application of strategic marketing planning}

A significant subset of the literature concerning the effectiveness of strategic marketing planning is that work which examines the actual level of application of these formal, rational processes.

Early studies of the degree to which companies adopted marketing as a strategic management process were encouraging. Hise ${ }^{44}$ for example, found that:

'1. To a large extent, both large and medium manufacturing firms have adopted the marketing concept.

2. The greatest degree of acceptance is found in the customer orientation of marketing programmes and in the organisational structure of the marketing department, particularly in the status provided the chief marketing executive.

3. Large firms are more fully committed to the marketing concept than medium ones. Although the difference is only slight as to some factors, a distinct pattern does exist.'

McNamara, ${ }^{45}$ suggested that adoption was diffusing from consumer to industrial companies. These studies suggested that marketing was becoming central to business planning, although there were clear variations across industry sectors, company sizes and functional areas. Even among these earlier studies, however, there were indications that, while many firms espoused the values of marketing, their actual behaviour contradicted this. ${ }^{46,47}$ The literature in this area gradually moved towards the conclusion that strategic 
marketing planning was widely claimed but much less practised. ${ }^{48-52}$ The aggregate view amongst researchers considering this area is consistent with the view of Martin $^{53}$ that:

'Corporate planning as advocated by the theorists is not practised in any developed form by large corporations'.

Further work went on to describe the realities of marketing planning, as compared to the espoused activity. This work described how rational marketing planning was subverted by less rational decision-making processes. ${ }^{54-58}$ The consensus amongst these authors as to the deviation of actual marketing planning from the prescribed and espoused process is notable. Less clear is the mechanism underlying this deviation, although one piece of research does attempt to suggest a mechanism in behavioural terms. ${ }^{59}$

The related but more broadly based literature concerning strategic decision making reinforces the conclusion that rational planning, whatever its merits or otherwise as a prescription, is a 'poor description of reality'. ${ }^{60-61}$ This conclusion has been fully supported by exploratory fieldwork for this study, ${ }^{62}$ which shows that marketing practitioners in healthcare companies are generally unqualified and make little use of the tools of strategic marketing planning. Contrasting this, some researchers have recently suggested that strategic marketing planning is a thriving and popular process in many companies. ${ }^{63}$ This work, based on selfadministered postal surveys, is, however, open to significant criticism of its internal validity.

Some of the work in this area is open to the criticism that it is overly concerned with semantics. It could easily be argued that a strategic marketing plan that does not use the terminology and structure of the accepted texts is still a strategic marketing plan. Studies of the use of the most important tools in strategic marketing planning reinforce the impression that it is often honoured in name and abused in practice, however.

The first example of these criticisms lies in the use of segmentation, which is fundamental to strategic marketing planning. Strategically, segmentation is meant to be both customer driven and reflected in organisational structure. The reality is that most companies rely on customer categorisation bolted on to the customer contact part of the company. ${ }^{64}$

The second example concerns SWOT analysis, the central technique for aligning the internal and external environments and, therefore, defining the key issues to be addressed. Examination of practice reveals that, although widely quoted, the technique is usually reduced to a 'subjective listing exercise', identifying none of the key issues that are the intended output of the technique. ${ }^{65,66}$ The abuse of these two fundamental tools suggests that the lack of commitment to prescriptive strategic marketing planning processes is a real phenomenon and not just a matter of semantics.

Further evidence of the real, and not just semantic, lack of use of the tools of strategic marketing planning is provided by a body of literature reviewed by Greenley \& Bayus $^{67}$ and summarised in Table 1.

Critical assessment of this body of literature therefore concludes that the prescriptive rational model of strategic marketing planning is not an accurate description of what occurs in many organisations. Further, the literature supports the observation that planning is replaced or supplemented by non-rational processes. The literature concerning the actual use of rational planning does not, however, explain this low level of use. This is an important gap in our knowledge. The lack of use of planning is highly significant to this study of strategy 
Table 1: The observed use of marketing planning techniques

\begin{tabular}{|c|c|c|c|}
\hline Study & Country & Focus & Outline of results \\
\hline Buzzell \& Wiersema ${ }^{68}$ & USA & Strategic planning & Limited use of formal planning methods \\
\hline $\begin{array}{l}\text { McColl-Kennedy \& } \\
\text { Keil }^{69}\end{array}$ & Australia & Marketing planning & Awareness and usage of methods low \\
\hline Greenley $^{70}$ & UK & Marketing planning & $\begin{array}{l}\text { Only } 24 \% \text { use portfolio analysis; half use } \\
\text { product life cycle (PLC) analysis }\end{array}$ \\
\hline Haspelagh $^{71}$ & USA & Strategic planning & Only $45 \%$ use portfolio analysis regularly \\
\hline Hopkins $^{72}$ & USA & Marketing planning & $\begin{array}{l}\text { A quarter use portfolio analysis, only } 13 \% \\
\text { use PLC analysis }\end{array}$ \\
\hline Hooley et al. ${ }^{73}$ & UK & Marketing planning & $\begin{array}{l}\text { Half use SWOT analysis, a third use PLC, } \\
\text { only a few use portfolio, profit impact of } \\
\text { market strategy (PIMS), perceptual mapping } \\
\text { and conjoint analysis }\end{array}$ \\
\hline Reid \& Hinckley ${ }^{74}$ & UK/Hong Kong & Strategic planning & $\begin{array}{l}\text { Little awareness of PIMS, portfolio } \\
\text { and PLC analysis }\end{array}$ \\
\hline Ross \& Silverblatt ${ }^{75}$ & USA & Strategic planning & $\begin{array}{l}\text { Half use portfolio analysis regularly, and a } \\
\text { quarter use PIMS regularly }\end{array}$ \\
\hline Verhage \& Waarts ${ }^{76}$ & Netherlands & Strategic planning & $\begin{array}{l}15 \% \text { use portfolio analysis, } 27 \% \text { use PLC } \\
\text { with } 62 \% \text { using SWOT }\end{array}$ \\
\hline Wittink \& Cattin ${ }^{77}$ & USA & Marketing planning & $\begin{array}{l}\text { Limited use of conjoint analysis by market } \\
\text { research (MR) consultants }\end{array}$ \\
\hline Wood \& LaForge ${ }^{78}$ & USA & Strategic planning & Portfolio analysis used by $67 \%$ of sample \\
\hline
\end{tabular}

making effectiveness, and reinforces the hybrid process picture suggested by the strategy process literature (see Figure 1 above). If rational processes contribute to effectiveness but are not used, this suggests that they are limited in their utility rather than their effectiveness. This is a critical distinction. Taken together, the literature suggests that strategic marketing planning can work, but that organisations find it too difficult to use in practice. This is entirely consistent with a related stream of work calling for improvements in the marketing strategy process. ${ }^{79-84}$ This stream of work calls, in particular, for the development of marketing strategy making processes to be more appropriate to the context in which they operate, pointing out that marketing is more context dependent than other disciplines and that its 'law-like generalisations' only still apply if the context has not changed. ${ }^{85}$ This sentiment is also echoed in the work that considers the antecedents and consequences of marketing strategy making: ${ }^{86}$

\footnotetext{
'Because environmental turbulence demonstrated a significant association with learning and market performance and moderated the relationship between situational analysis and performance, further research should examine other moderators and controls, such as market characteristics, as well as other dimensions of the environment, such as environmental munificence and complexity.'
}

Hence that part of the literature which considers the application of marketing planning supports two assertions: that marketing planning is not extensively used despite its contribution to effectiveness, and that the reasons for this seem to lie in the difficulty of application in the context of internal and external conditions. This suggests that future research should consider not simply the processes of 
marketing strategy making and the content of the resultant strategy, but also the internal and external contexts in which the process operates. The extant literature concerning the relationship between marketing strategy making processes and their internal and external contexts is therefore considered in the following two sections.

\section{Internal mediators of the effectiveness of marketing strategy making processes}

Examples of, and reasons for, the failures of organisations to implement strategic marketing planning are well documented. ${ }^{87,88}$ Broadly, these have been categorised as either 'cognitive' or 'cultural' barriers. ${ }^{89}$ A more expansive classification of these barriers is given by one review work. ${ }^{90}$ As well as culture, these authors cite management roles, management cognition (ie knowledge of marketing techniques), systems and procedures, resource allocation and data availability as moderators of rational planning use. Other researchers expand this work to include barriers across the organisation as a whole. ${ }^{91,92}$ Ruekert \& Walker, ${ }^{93}$ in an attempt to develop a general framework from social systems theory and resource dependence models, conclude:

\footnotetext{
'Much of the horizontal interaction among departments is informal. Consequently, it is outside the prescribed structures of the organisation chart, the substantive content of the marketing plan and the formal authority of the marketing and other functional managers. Despite the informal nature of such interactions, however, their critical role in the successful implementation of marketing strategies is widely recognised'.
}

Researchers looking at how strategy making varies between organisations reinforce this conclusion. Investigations of strategic planning in small and medium enterprises (SMEs), for instance, point to lack of resources and knowledge as barriers to rational planning. ${ }^{94-96}$ Systems, procedures and structures are also linked to the degree to which strategic planning can be used. In some organisational structures 'formal planning may cause internal contradictions and endanger and organisation's viability'. ${ }^{97}$ Ruekert, ${ }^{98}$ using different terminology but covering the same point, went further in saying:

'The degree to which an organisation can increase its market orientation is inextricably linked to the organisational structures, systems and processes created to sustain them'.

Other authors building on this work suggest, however, that these tangible reasons reflect fundamental differences in small firms' beliefs about themselves ${ }^{99}$ and other cultural factors. ${ }^{100}$

More recently, empirical work by Marginson ${ }^{101}$ examining the interaction between management control systems and strategy making has demonstrated that lower- and middle-management control systems have an important influence on strategy making:

'Findings suggest that belief systems influence managers initiation or 'triggering' decisions, the use of administrative controls affects the location of strategic initiatives and may lead to the polarization of roles, and simultaneous emphasis on a range of key performance indicators can create a bias towards one set of measures and against another'.

This work suggests a connection between beliefs and systems that is echoed by other researchers. While tangible factors such as systems or structures are acknowledged to affect strategy making, authors building on this work suggest that these tangible reasons reflect 'fundamental differences in small firms' beliefs about themselves ${ }^{102}$ and other cultural factors. ${ }^{103}$

Consistent with this theme of hindrance of strategy process by organisational cultural factors is that stream of work 
concerned with the strategy making from the perspective of organisational discourse. This work, based on social systems theory, depicts the strategy process as 'a technological and appropriative social practice"104 and strategic episodes as 'the effective locus of strategic practice and the interaction between strategic and operating routines'. ${ }^{105}$ Using the social discourse perspective, some researchers have suggested that failures of organisational strategy making can be attributed to cultural factors, in particular: ${ }^{106}$

'We argue the failure in organisational strategising can be understood as resulting from the interplay of certain elements of organisational discourse and specific kinds of political behaviour'.

Thus two streams of literature suggest different ways in which internal factors mediate the performance of marketing strategy making processes. The earlier work suggests tangible factors such as systems and structures; the latter work suggests less tangible factors associated with organisational discourse. These views need not be mutually exclusive, however, and can indeed be seen as two aspects of one phenomenon if they are both, as is discussed next, regarded as artefacts of organisational culture.

The influence of organisational culture on marketing planning is the subject of a comprehensive stream of work by one author, Harris, and his colleagues. Investigating the interaction between culture and strategic marketing planning, he supports the idea that the cultural context is critical to the initiation and implementation of marketing planning. ${ }^{107-114}$ This prolific body of work considers many different aspects of the culture/marketing planning interaction but is perhaps best summarised in the conclusions concerning one company: ${ }^{115}$

'The study finds that six entrenched values appear to have impeded the initiation of planning within the company. These are: reactiveness, management activities and practice, compartmentalisation, short-term cost orientation, internal focus and stability'.

Thus, it is argued, various streams of work, each looking at internal mediators of planning performance, converge on the underlying significance of culture. The connection between tangible barriers to planning and the firm's beliefs, values and culture suggests that culture is a fundamental root cause for the ineffective implementation of strategic marketing planning. If tangible barriers, such as lack of resources and extant systems, are simply manifestations of organisational culture, then there is really only one internal barrier to strategic marketing planning, namely organisational culture. This tentative conclusion, based on the empirical observation of failures in strategic marketing planning, is reinforced by the organisational culture literature, as discussed in the following paragraph.

The literature concerned with organisational culture consists of two very different philosophical traditions. The first, essentially positivist, stems from the earlier body of literature on organisational climate, ${ }^{116-117}$ and is strongly quantitative in its approach. ${ }^{118-121}$ The second, essentially phenomenological, has its origins in anthropology ${ }^{122,123}$ and claims sharp epistemological divisions with the quantitative approach. Despite this philosophical schism, there exists a core of agreement about the nature and significance of organisational culture. Both positivists and phenomenologists see culture as being 'a means by which the organisation aligns itself to the external environment" ${ }^{\text {"124 }}$ and that it 'regulates internal transactions'. ${ }^{125}$ Similarly, both schools see organisational culture as multilayered. ${ }^{126,127}$

A second point of consensus exists between the positivist and phenomenological schools of 
organisational culture. This is that culture is, as Drucker puts it, 'persistent and pervasive'. ${ }^{128}$ Studies of organisational culture support the belief that the phenomenon is very difficult to manage. ${ }^{129-131}$ Legge $^{132}$ holds the view that 'the empirical evidence supports the difficulty of cultural change' while Ogbonna ${ }^{133}$ argues that much perceived cultural change is in fact 'resigned behavioural compliance', and not cultural change at all.

Where cultural change is achieved, it is usually the result not of dramatic change, but of managing the 'natural dynamic flux of culture' via the use of symbolism. ${ }^{134}$

Even if organisational culture were open to easy manipulation, this risks lessening any positive aspects of the extant organisational culture, ${ }^{135,136}$ decreasing organisational efficiency by increasing the intangible costs of internal transactions ${ }^{137}$ and other unintended consequences of cultural intervention. ${ }^{138}$

Synthesising the culture and planning mediators' literature suggests both a cause and mechanism for the effectiveness of marketing strategy process. Strategic marketing planning, acting as an explicit process of alignment between the organisation and the market, necessarily interacts with organisational culture, an implicit process of alignment. Either positive or negative interaction may be expected. This interaction is seen via systems, structures and other cultural artefacts, but has its roots in the cultural assumptions that underlie those artefacts. Attempts to change organisational culture to support the marketing strategy making process are problematic. This suggests that the strategy process effectiveness might be linked to, and achieved by, adaptation of the process to the culture.

This concept of fit between marketingstrategy-making process and culture is well supported by other researchers. Some researchers either implicitly or explicitly recognise planning and culture as two parallel and interacting processes for internal/external alignment ${ }^{139-141}$ and call for 'a culture-driven contingency approach'. ${ }^{142}$ This is consistent with studies in the organisational behaviour literature, which also correlate the fit between the organisational culture and the planning process with organisational effectiveness: ${ }^{143}$

'All other things being equal, the greater the total degree of congruence between the various components (of an organisation) the more effective will be organisational behaviour at multiple levels'.

Also: ${ }^{144}$

'For better or worse a corporate culture has a major impact on a company's ability to carry out objectives and plans, especially when the company is changing strategic direction'.

Similarly, the idea of culturally congruent planning is consistent with theories that management skills are culturally specific ${ }^{145}$ and that strategy formulation must recognise behavioural as well as mechanical aspects of organisational processes. ${ }^{146}$ Other researchers, from different perspectives, have pointed to the observed importance of organisational culture to strategy formation and implementation, ${ }^{147-149}$ without referring specifically to the alignment function of both the phenomenon and the management process. More specifically, the existence of appropriate organisational values as a prerequisite to marketing effectiveness has been identified, ${ }^{150,151}$ and is at the root of the marketing orientation literature. This last body of work suggests a clear association between marketing orientation and performance. ${ }^{152-157}$ The general tenor of this work is that market orientation is associated with superior performance, although the most recent work in this area suggests, however, that proponents of marketing orientation have addressed neither the methodological criticisms implied by the organisational 
effectiveness literature nor the potential difficulties and risks of cultural intervention. ${ }^{158}$ Finally, the concept that marketing strategy process is affected by the level of market orientation is supported by the work showing that both rational and incremental processes operate in market-oriented companies. ${ }^{159}$

Hence a very broad body of literature supports the idea that the effectiveness of marketing strategy making processes is related to its fit with the organisational context, at the root of which is pervasive and persistent organisational culture. This concept is not new. It was one of the conclusions of one of the earliest $\mathrm{PhDs}$ in strategic marketing planning. ${ }^{160} \mathrm{~A}$ mismatch between culture and process would suggest at least a partial explanation for the limited adoption of a known contributor to organisational success. This consideration of internal factors is not likely, however, to be a complete explanation of marketing strategy making process effectiveness. To be so would imply that external market factors are of no importance. The importance of external market factors in mediating marketing strategy making processes is discussed in the following section.

\section{External mediators of the effectiveness of marketing strategy making processes}

Both the marketing strategy literature and the broader strategic management literature point to the need to consider external mediators and their impact on the effectiveness of strategy making processes. From the many possible dimensions of the market environment, two broad themes emerge as being especially relevant.

The first theme is the impact of market turbulence. Planning is noted to have dysfunctional effects in uncertain and inefficient markets. ${ }^{161}$ Similarly, research in high-velocity environments indicates that 'planning formality may be negatively associated with performance ${ }^{162}$ (see also Eisenhardt ${ }^{163}$ and Eisenhardt \& Sull ${ }^{164}$ ).

The second theme is the significance of market complexity. This is supported by work showing the relationship between the comprehensiveness of planning and its effectiveness. ${ }^{165-167}$ Many of the arguments concerning the impact of external context on marketing planning processes have been consolidated by Speed and his coworkers ${ }^{168,169}$ who contend that "external context affects decision character, decision process and decision outcome.' Supporting the importance of external factors from a slightly different perspective is work correlating planning to effectiveness in hostile environments and for 'mechanistic' cultures, while advocating emergent processes in benign environments and 'organic' structures. ${ }^{170}$

This stream of work suggests, therefore, that the effectiveness of strategy development processes is mediated by external market contingencies. Further, it suggests that market turbulence and market complexity are the two most significant external mediators of strategy process effectiveness. The consensus around this is indicated by the fact that this was the common ground in the debate between Mintzberg ${ }^{171}$ and Ansoff. ${ }^{172}$ This stream of work also gives some indication of the nature of appropriate fit, or congruence, between strategy making processes and market conditions; complexity is seen to favour rational planning while turbulence is seen to favour less rational approaches. This, however, is the limit of the conclusions that can be drawn from this work, which retains three important weaknesses.

The first weakness is that the work relating strategy process to effectiveness remains wedded to the measurement of organisational outputs rather than strategy process outputs, and thus fails to answer the criticisms associated with this 
approach, as discussed earlier. Secondly, the empirical work does not allow for simultaneous internal and external mediation of the strategy making process, hence failing to distinguish between the effects of internal and external mediators. Thirdly, the work comes, almost entirely, from the perspective of proving or refuting the effectiveness of rational planning. It therefore tends to characterise strategy making processes along a simple planning/non-planning dimension. As the earlier section concerning hybrid strategy processes suggests, this is a simplistic approach to understanding actual marketing strategy making processes. The literature on external mediators of strategy making process effectiveness therefore suggests that external mediation occurs and indicates dimensions of process/market fit, but leaves unanswered important questions about the effectiveness of different strategy process hybrids in differing market conditions.

\section{A contingency theory explanation of marketing strategy making process effectiveness}

The work summarised and criticised above suggests that both internal cultural factors and external market factors impact upon the effectiveness of marketing strategy making processes. This clearly suggests that a contingency approach might be useful in understanding and explaining the effectiveness of marketing strategy making processes.

Contingency theory is, of course, a very broad approach covering numerous bodies of literature. Thompson ${ }^{173}$ usefully describes the origins of the contingency approach as being the intersection of various streams of organisation theory including general systems theory, open systems theory and behavioural theory. Theoretical and practical contributions are seen to be derived from contingency theory through:
- identifying important contingency variables that distinguish between contexts

- grouping similar contexts based on these contingency approaches

- determining the most effective internal organisational designs or responses in each major group.

The approach has been used 'both implicitly and explicitly in much marketing research. ${ }^{174}$

Relevant to this work, contingency approaches are seen as particularly useful in strategy research because they improve on the generalisability of single in-depth case studies, while providing greater depth than large-sample, statistically based work which de-emphasises contextual differences. ${ }^{175,176}$

Much of the research, criticised above, on the effectiveness and mediating variables of strategic marketing planning adopts the contingency approach. This body of work appears, however, to have two significant flaws when applied to understanding marketing strategy making processes in the context of the extant knowledge reviewed above. First, the work concerns itself with contingent dimensions of either the internal or the external environment in which marketing operates. This is at variance with the empirical findings discussed above that suggest that both internal and external contingencies impact on the effectiveness of marketing strategy making processes. Secondly, the work considers only one dimension of strategy process, that of its rationality or formality. This does not make sufficient allowance for the complexity of hybrid marketing strategy making processes.

One stream of that work does, however, suggest some ways in which the theory of marketing strategy process might be developed. One of the early seminal works in the contingency tradition of organisational theory (Lawrence \& Lorsch ${ }^{177}$ ) developed from the concept of 
the organisation as an open system, with interaction between its different subcomponents. Based on this concept, the authors developed concepts of functional differentiation, specialisation and integration as bases of organisational effectiveness. Building on this work, other researchers from a sociological perspective developed the theory that management processes are most effective when they are congruent with both their microenvironment and the macroenvironment: ${ }^{178,179}$

'Contingency theory postulates that the effectiveness of the organisation in coping with the demands of its environment is contingent upon the elements of the various subsystems which comprise the organisation being designed in accordance with the demands of the environment (or, more accurately, the subenvironments) with which they interact; this implies that that the elements of the different subsystems must be congruent in terms of the characteristics along each of the basic dimensions by which they are defined. We call this the congruency hypothesis'.

Interestingly, these researchers (Burrell and Morgan) reinforce the conclusions of the preceding parts of this literature review by making specific reference to market complexity and turbulence and to organisational culture as important dimensions of the external and internal environments.

This idea of effectiveness being a function of congruency, described by the above-mentioned researchers as the congruency hypothesis, represents a significant step forward in thinking from earlier, simpler work. Significantly, by including all of the sub-environments in which the organisational sub-systems operate, the congruency hypotheses incorporate the simultaneous importance of both internal and external contingencies to the effectiveness of any management process. The congruency hypotheses, when applied specifically to the process of marketing strategy making, suggest a potential explanation for the effectiveness or otherwise of any strategy-making process. Namely, that the effectiveness of a marketing strategy making process is contingent upon its congruence with both the external market environment (macrocongruence) and the internal environment (microcongruence). Using both Burrell and Morgan's own ideas and those derived from the literature review, market complexity, turbulence and organisational culture seem to converge as the factors important to achieving congruence and therefore effectiveness.

In their favour, the congruency hypotheses allow for both the organisational and market contingencies suggested by the literature already discussed. Against this, they do not, specifically, suggest the dimensions of the internal or external environment of most importance to strategy making effectiveness. Nor do they specify the nature of success for that process. Nor does the literature contain empirical applications of Burrell and Morgan's hypotheses. Taken together with the preceding literature review, however, contingency theory, and specifically the congruency hypotheses of Burrell and Morgan, suggest a theoretical basis upon which an explanation of the effectiveness of marketing strategy making may be developed into a model of marketing strategy making process effectiveness that combines hybrid processes, internal and external mediators and the quality of marketing strategy in one comprehensive explanation. Further, the preceding literature review suggests that there are a number of areas in the literature in which the consensus is strong enough to suggest accepted extant knowledge upon which a putative model might be built. These are that:

- The content of a marketing strategy can be 
defined and that the properties of a strong marketing strategy can be differentiated from those of a weak marketing strategy. Hence the construct of contextindependent marketing strategy quality can be developed from the literature.

- The process of marketing strategy making is hybrid with multiple dimensions and therefore more complex that suggested by simple measures of planning formality. Hence the construct of the hybrid marketing strategy making process can be developed from the literature.

- The relationship between the nature of the hybrid marketing strategy making process employed and the properties of the resultant strategy are mediated by external market factors. Hence an externally mediated model of the relationship between strategy process and strategy properties is suggested by the literature.

- The relationship between the nature of the hybrid marketing strategy making process employed and the properties of the resultant strategy are mediated by internal, cultural factors. Hence an internally mediated model of the relationship between strategy process and strategy properties is suggested by the literature.

- The effectiveness of the organisational subsystem of marketing strategy making is dependent upon its congruency with both its internal and external sub-environments. Hence a model of the relationship between

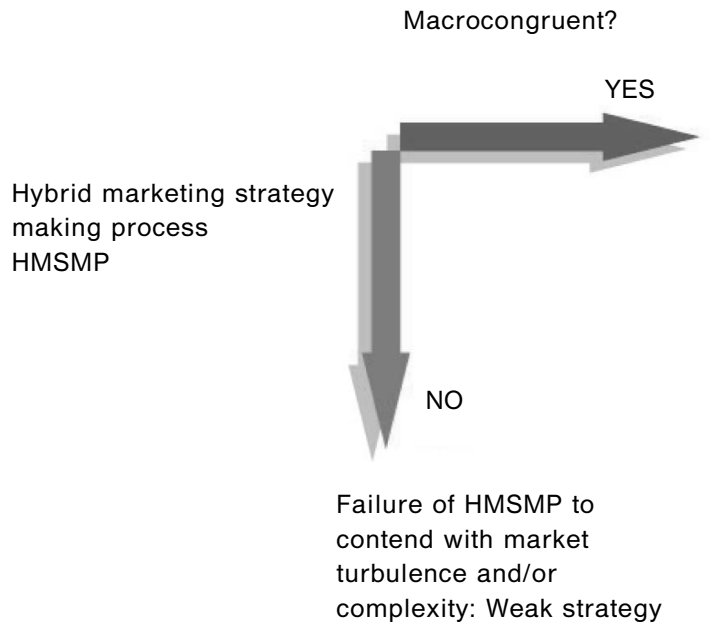

strategy process and strategy properties that is both internally and externally mediated is suggested by the literature.

Taken together, these areas of extant knowledge can be taken to form a putative model to explain the relationship between the hybrid marketing strategy making process employed and the properties of the resultant marketing strategy. Such a model is illustrated in Figure 2.

As indicated above, the literature review suggests likely dimensions that might help to operationalise each of the constructs involved in this model.

- Strategy quality: can be seen as the degree or otherwise to which the marketing strategy has the properties of a strong strategy identified in the extant literature.

- Strategy process: can be characterised along three dimensions, namely the proportion of rational, command and incremental processes that go to make up the hybrid

- External environment: while undoubtedly a complex construct can, in part, be characterised along the two dimensions most frequently cited as impacting on strategy process effectiveness, namely market complexity and market turbulence.

- Internal environment: while also a complex construct, can in part be characterised as those artefacts of organisational culture

Microcongruent?

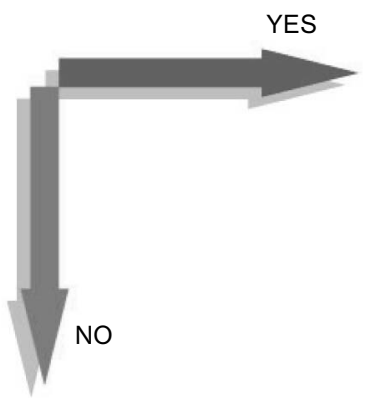

HMSMP is congruent to both market and organisational culture: Strong strategy
Failure of HMSMP due to conflict with culture. Artefact clash, Culture wins: weak strategy

Figure 2: Combined congruency model 
most frequently cited as impacting on strategy process effectiveness, namely structures, systems and organisational habits.

- Macrocongruence: can be characterised as the degree to which the strategy making process manages the external environment, in particular, the degree to which the process manages market complexity or turbulence. Conversely, macroincongruence can be seen as the degree to which the strategy making process fails to manage market complexity or turbulence.

- Microcongruence: can be characterised as the degree to which the strategy-making process is supported by the internal environment, in particular, the degree to which the process is supported by cultural artefacts such as systems and structures and other organisational habits. Conversely, microincongruence can be seen as the degree to which the strategy making process is hindered by those artefacts.

This model, then, imperfectly characterised as it is, formed the basis of the research questions and propositions to follow and was the basis for operationalising the research.

\section{Research questions and methodology}

The objective of this research was to test and develop the combined congruency model described above. This was operationalised in relation to the research question:

\section{Do the congruency hypotheses of Burrell and Morgan apply in the context of marketing strategy making processes?}

Hence four propositions were developed:

- Proposition P1: The degree to which an organisation's marketing strategy exhibits the properties associated with a strong strategy is proportional to the extent to which microcongruence (between strategy process and internal environment) and macrocongruence (between strategy process and market environment) are exhibited.

If supported by the research, this first proposition would provide support for the applicability of the congruency hypotheses in this context. It would not, however, provide conclusive proof of the hypotheses in this context.

As with all research, the issue of verification and falsification arises, as described by Popper, and summarised by Easterby-Smith et al. ${ }^{180}$

For purposes of testing the theory, therefore, it is also useful to consider alternatives to this proposition that would, if supported, disprove or modify the congruency hypotheses. These would include:

- Proposition P2: The degree to which an organisation's marketing strategy exhibits the properties associated with a strong strategy is unrelated to either microcongruence (between strategy process and internal environment) or macrocongruence (between strategy process and market environment).

This second proposition would be consistent with the views of those, such as prescriptive planners, who hold that one single type of strategy making process produces the strongest strategy.

Another alternative proposition would hold:

- Proposition P3: The degree to which an organisation's marketing strategy exhibits the properties associated with a strong strategy is related to the degree to which microcongruence (between strategy process and internal environment) is exhibited but not to the degree to which macrocongruence (between strategy process and market environment) is exhibited.

This third proposition would be consistent with the views of those who see organisational culture as the dominant, perhaps overriding, factor in determining the effectiveness of marketing strategy making processes. 
Conversely, a fourth proposition by which to test the theory that both types of congruence are necessary would be:

- Proposition P4: The degree to which an organisation's marketing strategy exhibits the properties associated with a strong strategy is related to the degree to which macrocongruence (between strategy process and market environment) is exhibited, but not the degree to which microcongruence (between strategy process and internal environment) is exhibited.

This fourth hypothesis would be consistent with the views of those who see external market contingencies as the dominant, perhaps overriding, factor in determining the effectiveness of marketing strategy making processes.

The research methodology employed is fully described in the first paper of this trilogy ${ }^{181}$ and in the $\mathrm{PhD}$ thesis resulting from this work. ${ }^{182}$ The companies examined are summarised in Table 2.

\section{RESEARCH FINDINGS}

An overview of the results is shown in Table 3 .

The companies studied were observed to work in a variety of market environments of varying complexity and turbulence, as

Table 2: Respondent overview

\begin{tabular}{|c|c|c|}
\hline Case & Company description & Respondents \\
\hline A & $\begin{array}{l}\text { The UK subsidiary of a global in-vitro diagnostics company, } \\
\text { specialising in one type of technology }\end{array}$ & $\begin{array}{l}\text { Marketing and Sales Director, Sales Manager, } \\
\text { Marketing Manager }\end{array}$ \\
\hline C & $\begin{array}{l}\text { The UK headquarters of a mostly UK medical } \\
\text { disposables company }\end{array}$ & $\begin{array}{l}\text { Managing Director, Sales Director, Marketing } \\
\text { Director }\end{array}$ \\
\hline$E$ & $\begin{array}{l}\text { The global headquarters of a first-rank pharmaceutical company, } \\
\text { with many therapeutic areas }\end{array}$ & $\begin{array}{l}\text { Sales Director, Marketing Director, } \\
\text { Business Development Director }\end{array}$ \\
\hline $\mathrm{F}$ & $\begin{array}{l}\text { The UK sales and marketing subsidiary of a first-rank } \\
\text { pharmaceutical company, with many therapeutic areas }\end{array}$ & $\begin{array}{l}\text { General Manager, Sales Director, Director of } \\
\text { Strategic Planning, Financial Controller }\end{array}$ \\
\hline I & $\begin{array}{l}\text { The UK headquarters of a medium-sized medical equipment } \\
\text { company, part of a larger multinational } \\
\text { group with global interests }\end{array}$ & $\begin{array}{l}\text { Managing Director, Marketing Director, Sales } \\
\text { Director }\end{array}$ \\
\hline J & $\begin{array}{l}\text { The UK Sales and Marketing subsidiary of a first-rank } \\
\text { pharmaceutical company, with many therapeutic areas }\end{array}$ & $\begin{array}{l}\text { General Manager of Hospital Division, Group } \\
\text { Product Manager }\end{array}$ \\
\hline $\mathrm{K}$ & $\begin{array}{l}\text { The UK headquarters of a first-rank medical } \\
\text { disposables company with global interests }\end{array}$ & $\begin{array}{l}\text { Marketing Manager, Internal Product Manager, UK } \\
\text { Product Manager }\end{array}$ \\
\hline L & $\begin{array}{l}\text { The UK sales and marketing subsidiary of a first-rank medical } \\
\text { devices company }\end{array}$ & $\begin{array}{l}\text { General Manager, Sales Manager, Marketing } \\
\text { Manager }\end{array}$ \\
\hline Q & $\begin{array}{l}\text { The UK sales and marketing subsidiary of a } \\
\text { second-tier pharmaceutical company, with many therapeutic } \\
\text { areas }\end{array}$ & $\begin{array}{l}\text { Marketing Director, Sales Manager, } \\
\text { Medical Director }\end{array}$ \\
\hline $\mathrm{R}$ & $\begin{array}{l}\text { The UK sales and marketing subsidiary of a } \\
\text { second-rank medical devices and pharmaceutical company }\end{array}$ & $\begin{array}{l}\text { Sales and Marketing Director, Sales Manager, } \\
\text { Medical Affairs Manager }\end{array}$ \\
\hline
\end{tabular}




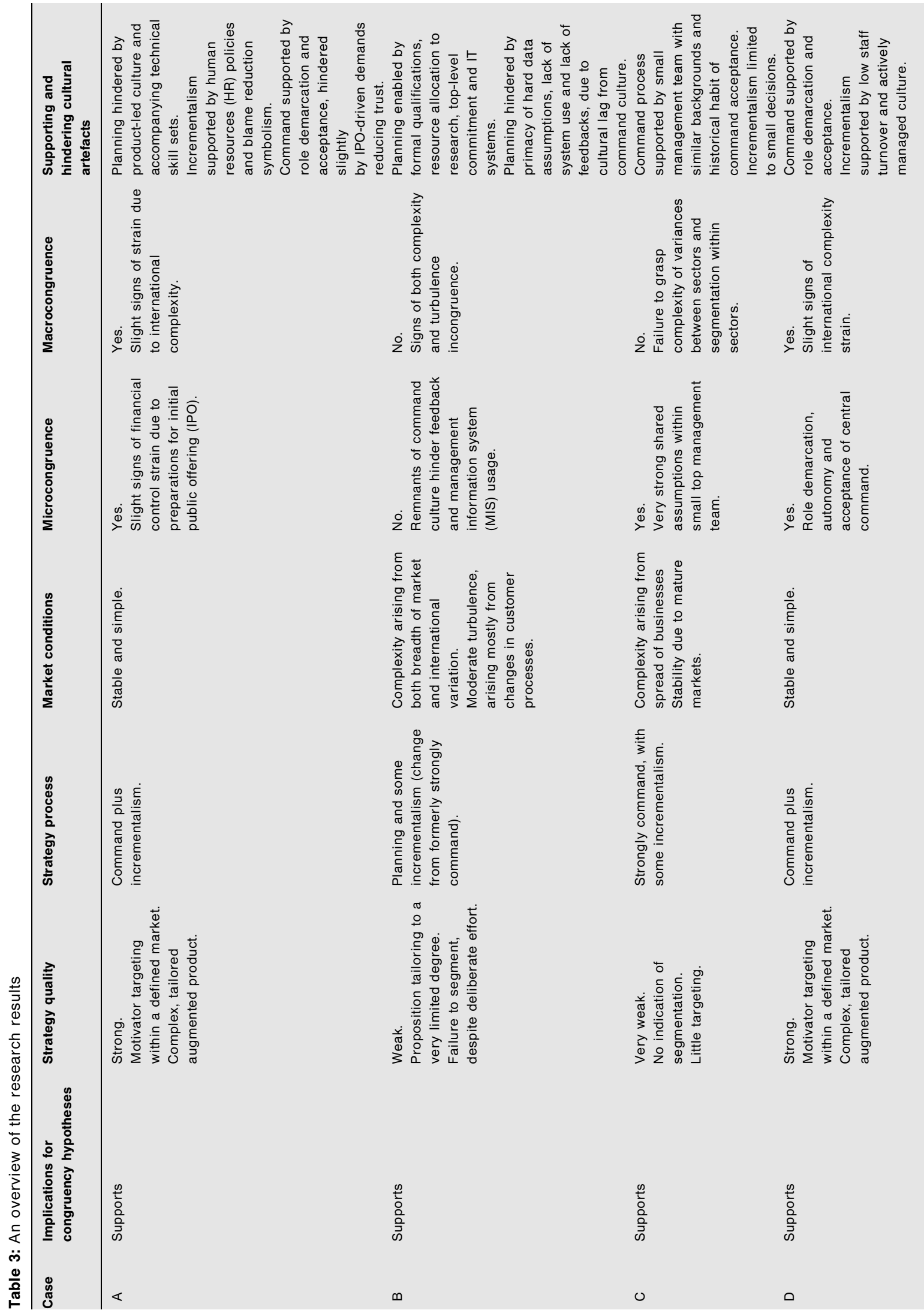




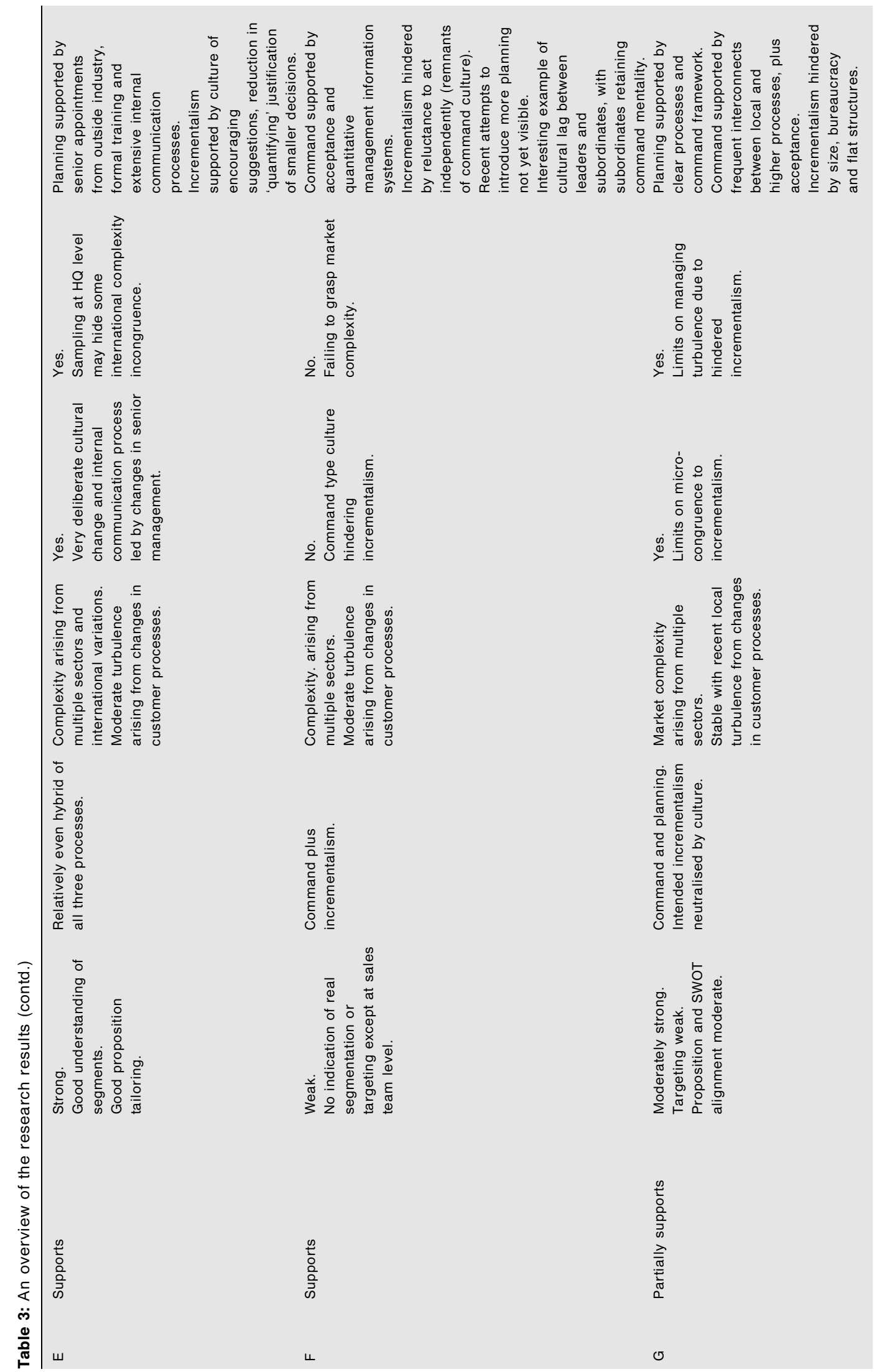




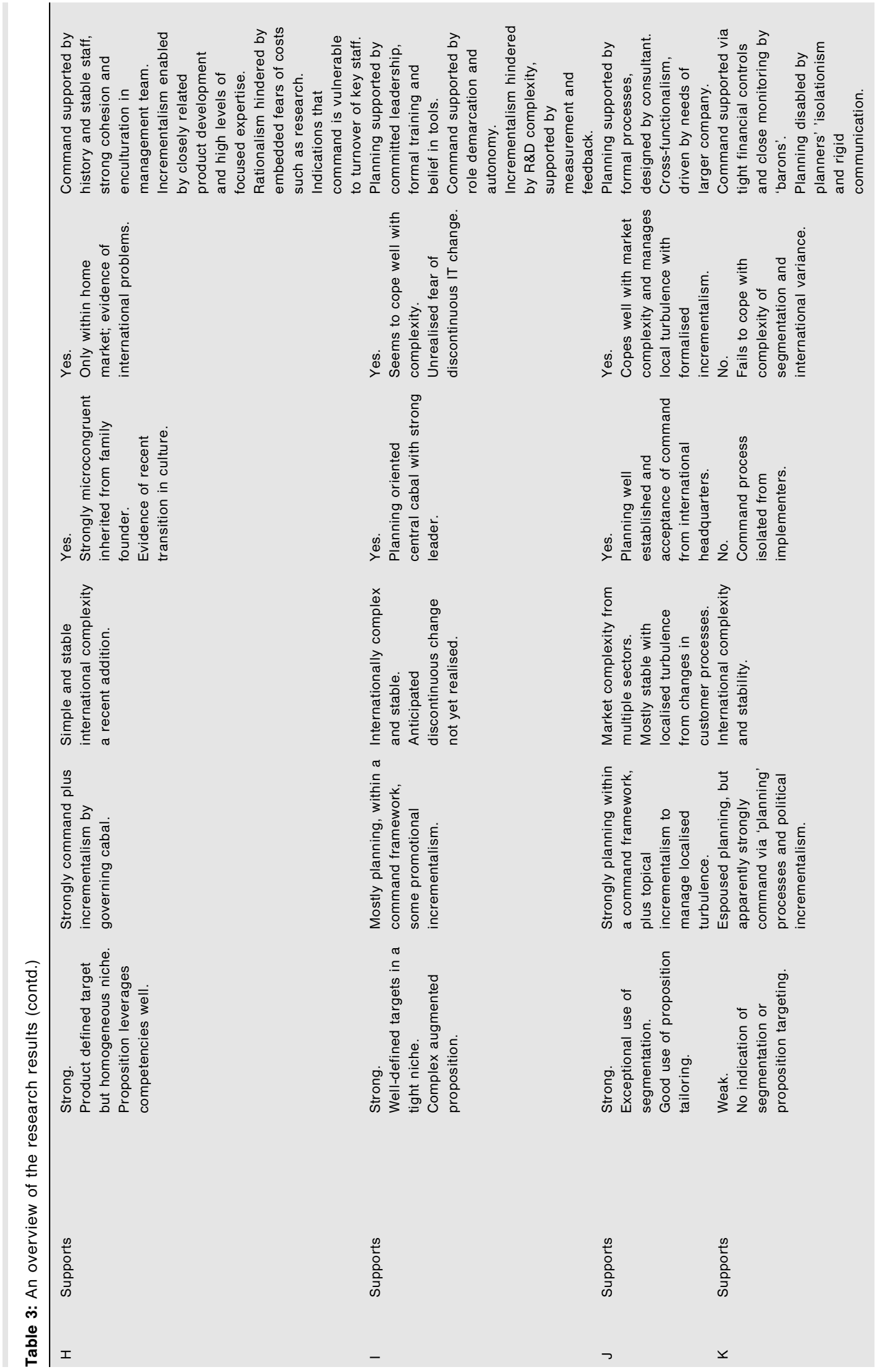




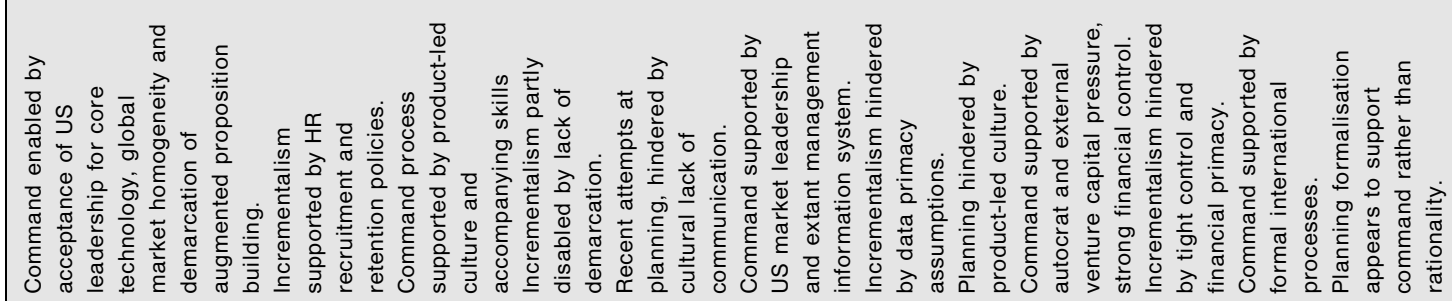

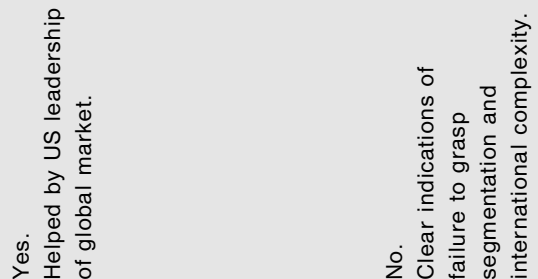
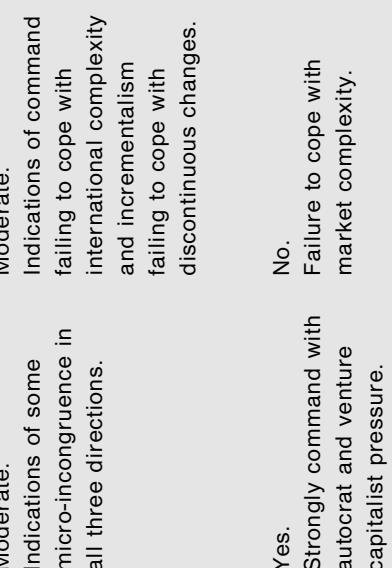

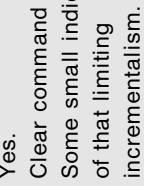

$\stackrel{0}{\frac{0}{2}}$
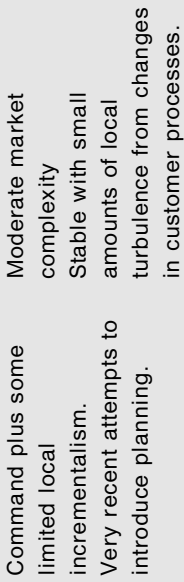

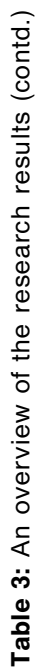
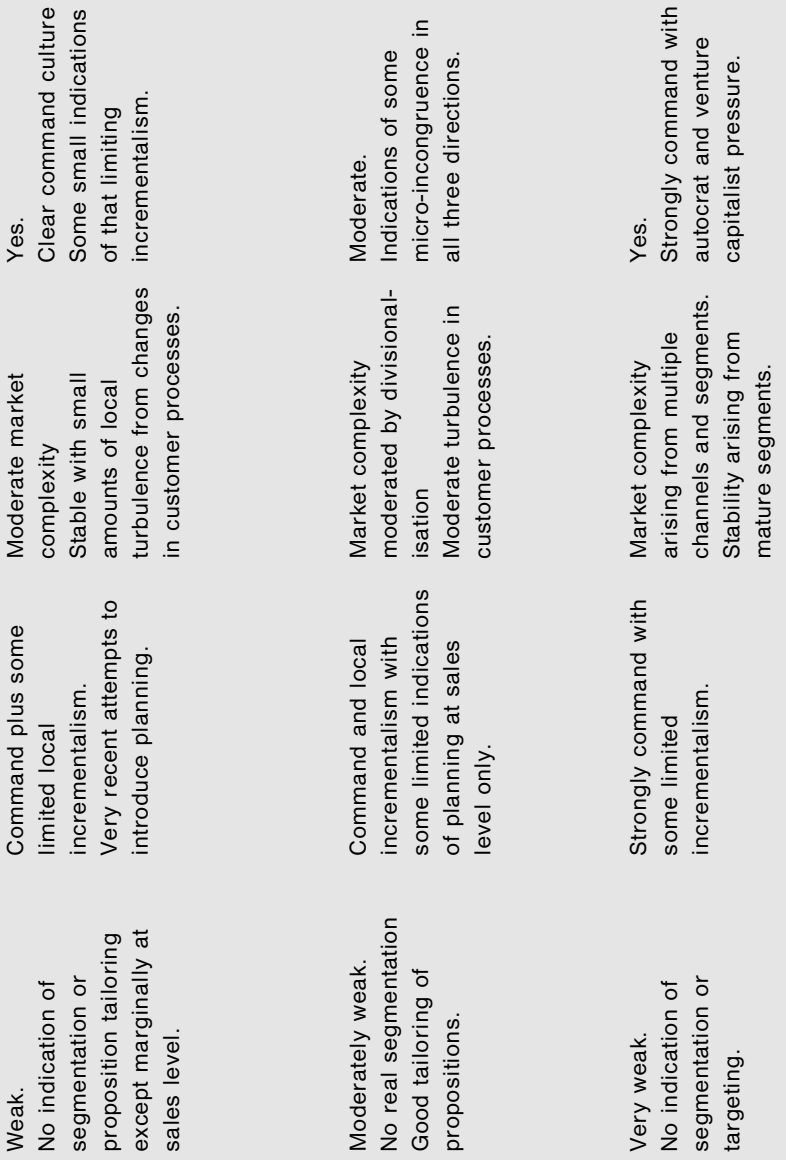

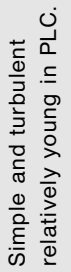

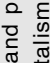

离

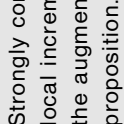
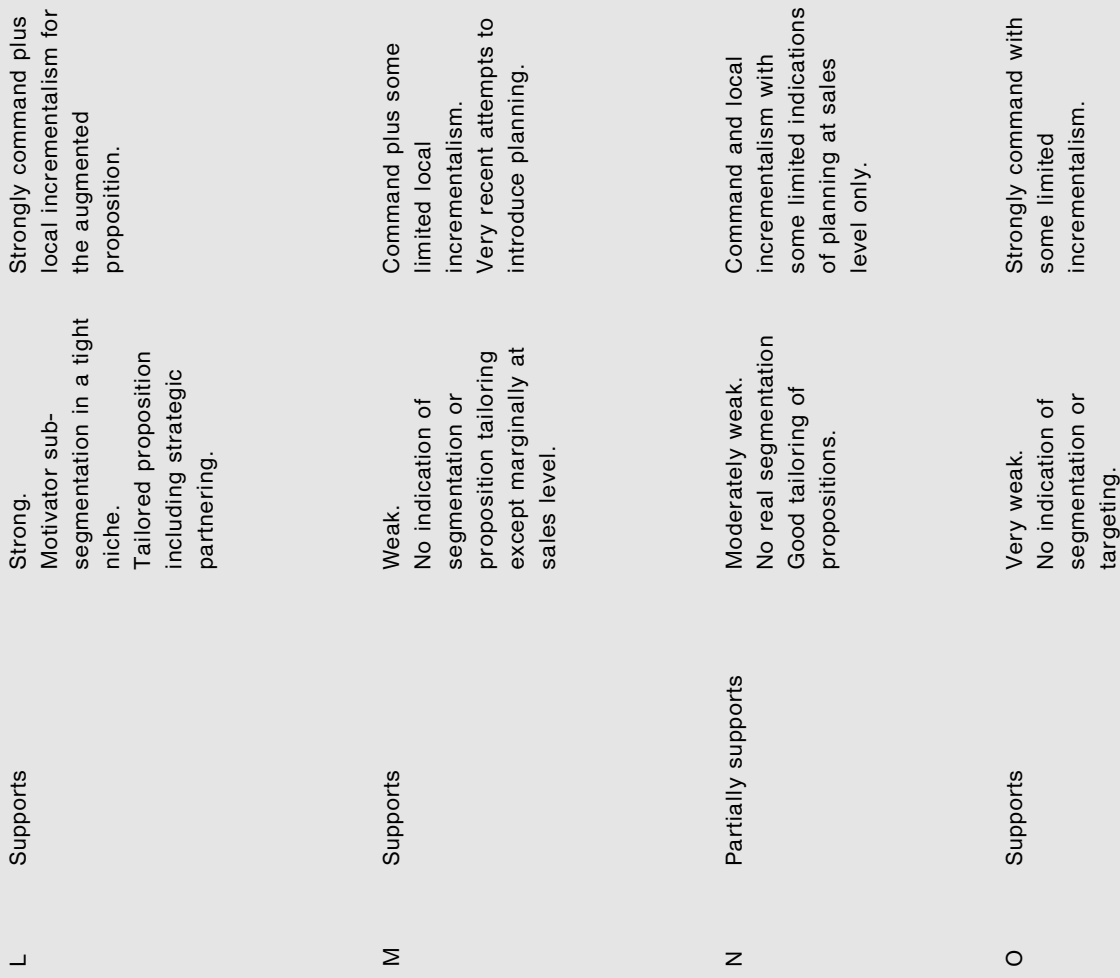

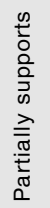

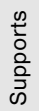

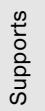
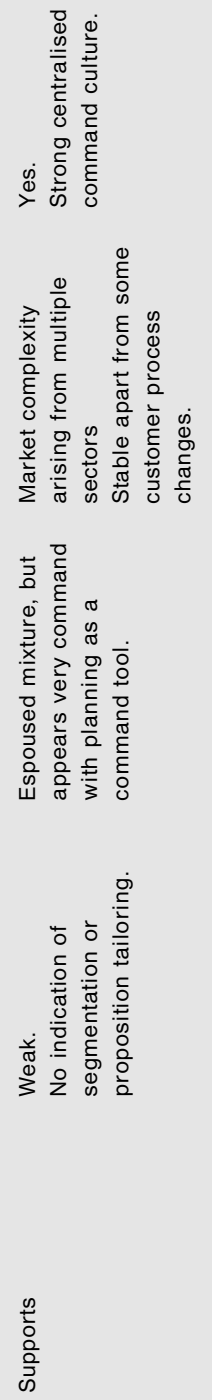

$\frac{2}{\frac{2}{2}}$ 


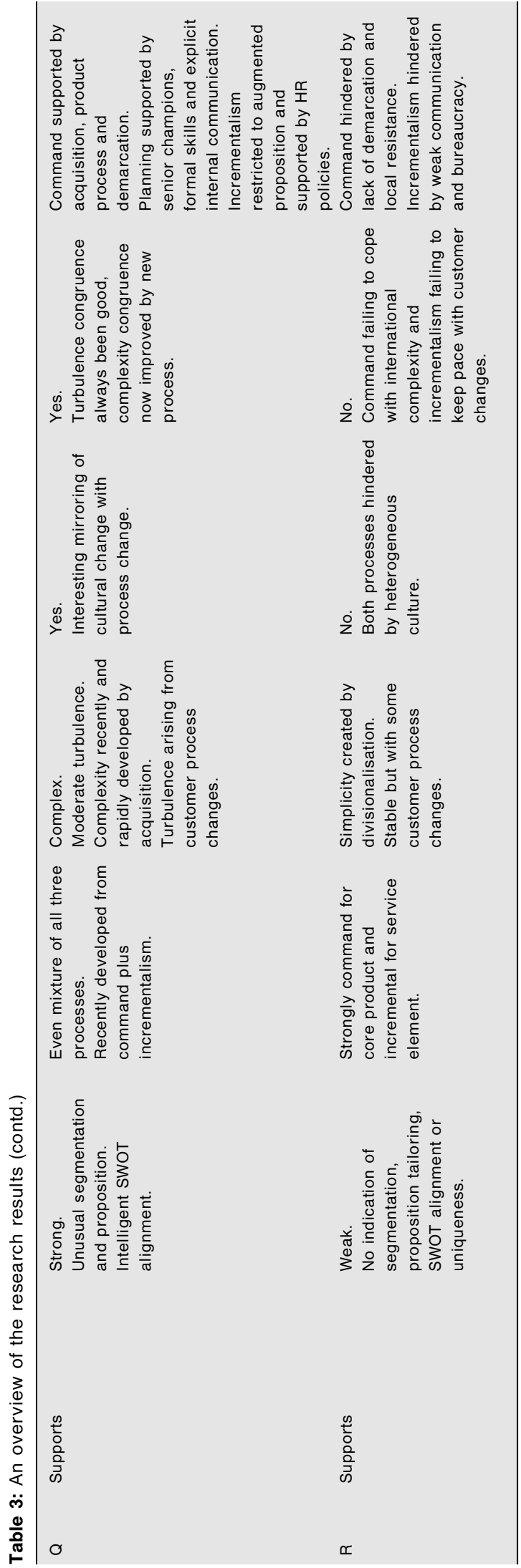




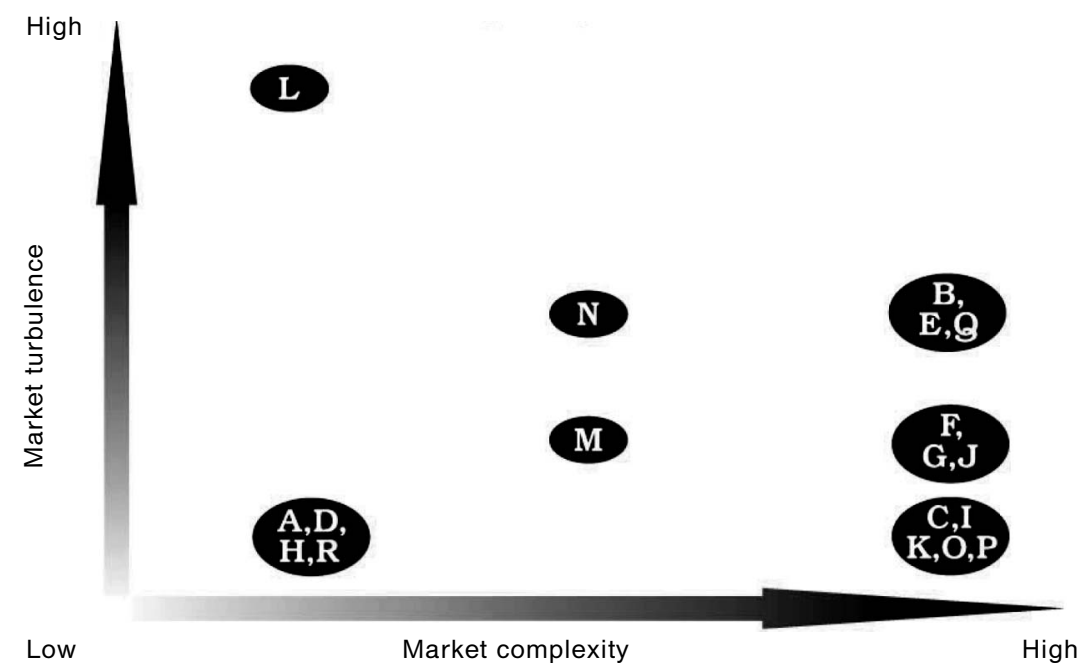

Figure 3: Distribution of cases in terms of relative market complexity and market turbulence

summarised in Figure 3. A bias towards stable markets was observed, however, which may be an artefact of the technically complex, heavily regulated nature of medical markets. The case study companies exhibited varying degrees of macrocongruence and microcongruence, as shown in Figure 4. Further, notable variations in marketing strategy quality were noted, as shown in Figure 5.

\section{CONCLUSIONS}

The findings described above support or refute the propositions as follows:

\section{Proposition P1}

These findings uphold proposition P1. All of the cases which exhibited the properties of a strong strategy also exhibited both macrocongruence and microcongruence. These were cases A, D, E, H, I, J, L and Q.

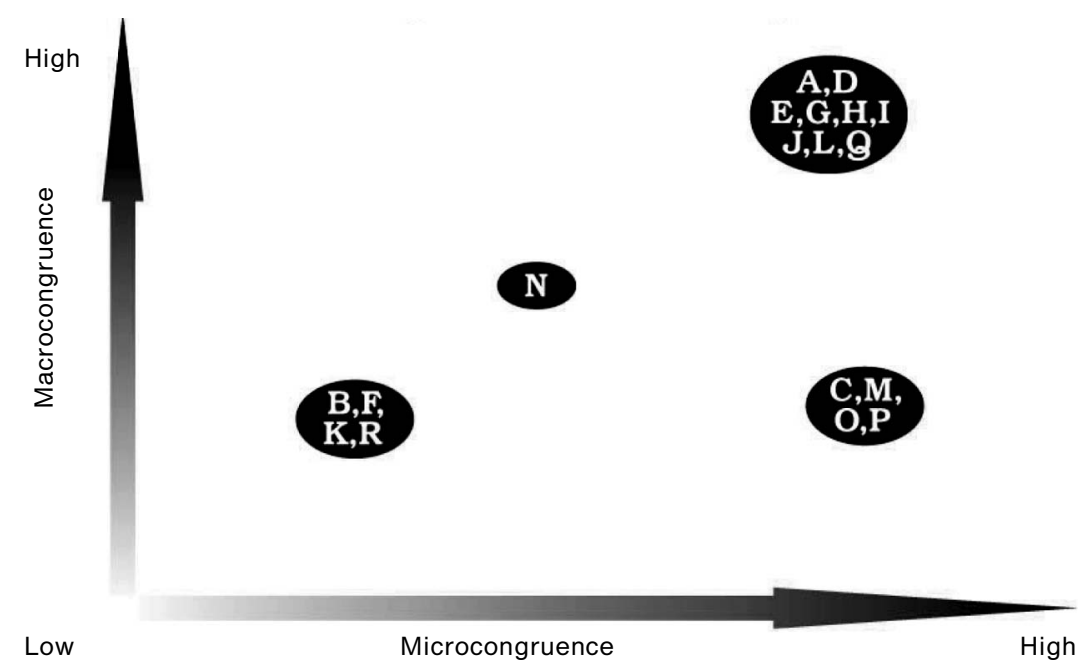

Figure 4: Distribution of cases in terms of macrocongruence and microcongruence 


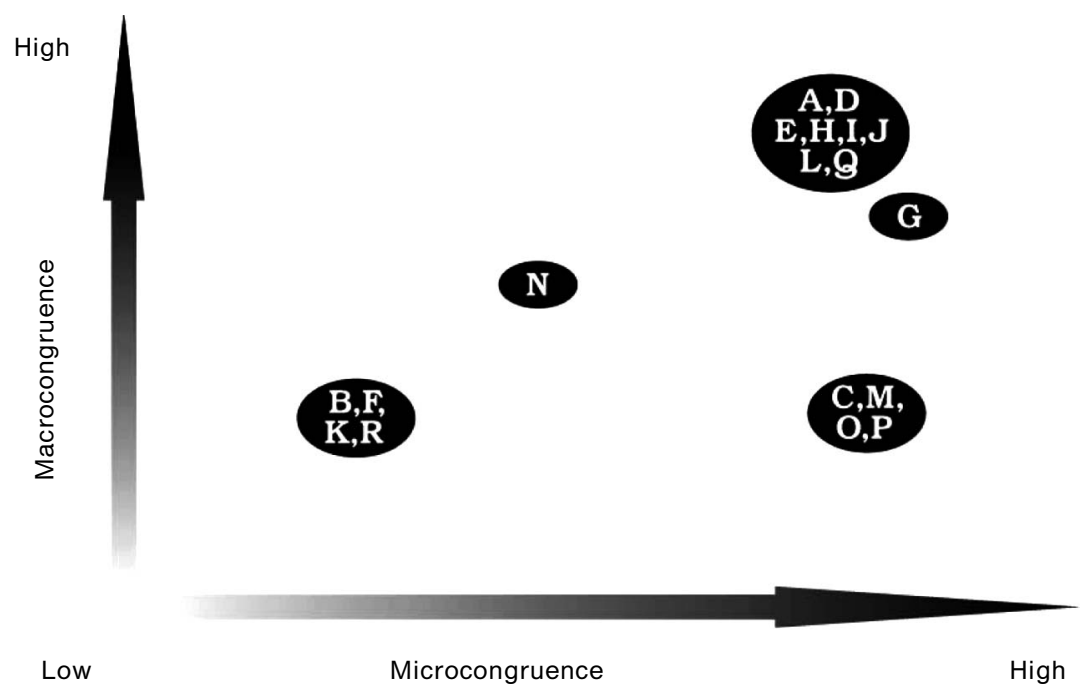

Figure 5: Strategy quality in relation to macrocongruence and microcongruence

By contrast, those cases which exhibited the properties of a weak strategy also exhibited a lack of either macrocongruence or both microcongruence and macrocongruence. These were cases $\mathrm{C}, \mathrm{M}$, $\mathrm{O}$ and $\mathrm{P}$ (lacking macrocongruence) and $\mathrm{B}, \mathrm{F}, \mathrm{K}$ and $\mathrm{R}$ (lacking both).

It is of interest that, while some cases which exhibited microcongruence lacked macrocongruence, the reverse was not found. In other words, no cases were found where the hybrid marketing strategy making process was congruent to the market without being congruent to the organisational culture. This might suggest that microcongruence is in some way an antecedent of macrocongruence. This study was not designed to examine this issue, and the findings do no more than suggest an association between the two phenomena, but it remains an interesting point.

Only two cases did not fully support proposition P1. Case G, which exhibited both microcongruence and macrocongruence, showed only a moderately strong strategy. No immediate explanation of this partial lack of support with the congruency is supported by the data. It must be borne in mind, however, that case $G$ offered only a single respondent and cannot therefore be considered wholly reliable. Case $\mathrm{N}$, offering three respondents, demonstrated mid-range values in each of the three variables (strategy quality, macrocongruence and microcongruence). While this does not refute proposition P1, nor does it fully support it.

The three other propositions offered are intended to falsify the congruency hypotheses, and are based upon other strands of the extant literature.

\section{Proposition P2}

Proposition P2 is intended to represent the position of those, such as prescriptive planners, who hold that one single type of strategy making process produces the strongest strategy, irrespective of the internal or external context in which it operates.

The findings of this work do not uphold this proposition. In addition to the strong correlation between strategy quality and combined congruency described above in support of P1, the lack of association between the type of hybrid marketing 
strategy making process and strategy quality refutes P2. Strong strategies were noted in cases with command and incremental processes (A and D), strongly command processes ( $\mathrm{H}$ and $\mathrm{L})$, planning and incrementalism processes (I and $\mathrm{J}$ ) and three-way hybrid processes (E and Q). Weak strategies were noted in cases of command and incremental processes ( $\mathrm{F}, \mathrm{M}$ and $\mathrm{R})$, strongly command processes $(\mathrm{C}$, $\mathrm{K}, \mathrm{O}$ and $\mathrm{P}$ ), and planning and incremental processes (B). Hence these findings do not support the universal use of any single hybrid marketing strategy making process, whatever its nature. Rather, these findings indicate that strategy quality is not simply a function of the hybrid marketing strategy making process but is indeed contingent upon the internal and external environments in which the process operates. Proposition P2 is not therefore upheld by these findings.

\section{Proposition P3}

Proposition P3 is intended to represent the position of those who see organisational culture as the dominant, perhaps overriding, factor in determining the effectiveness of marketing strategy making processes. Such a position minimises the importance of the external, market environment.

These findings do not uphold this proposition. Positive support for P3 would be provided by cases that exhibited microcongruence without macrocongruence and had strong strategies. Four cases (C,M, O and $\mathrm{P}$ ) exhibited microcongruence but did not exhibit macrocongruence. All of these cases had strategies which were weak. By contrast, those eight cases (A, D, E, H, I, J, $\mathrm{L}$ and $\mathrm{Q})$ which exhibited microcongruence and also exhibited macrocongruence all had strong strategies.

In addition to strong strategies in cases of microcongruence without macrocongruence, there is another set of possible conditions that might provide negative support for P3. This would be the existence of weak strategies in cases of macrocongruence without

microcongruence. No cases of that type existed in the sample, however. Hence proposition $\mathrm{P} 3$ is not upheld by these findings.

It is interesting that the majority, 12 out of 18 cases, exhibited microcongruence. This is partially supportive of those who see strategy process as largely an artefact of organisational culture. Such a culturedominant view would hold that the organisational culture either leads to the strategy process or moulds it to fit with the culture. This would appear to be the situation in many of the cases $(\mathrm{A}, \mathrm{C}, \mathrm{D}, \mathrm{H}$, I, L, M and P). A minority of the cases exhibited evidence of having adapted the organisational culture to fit the strategy process (E, I, J and Q) however. A notable characteristic of all four of these examples of cultural adaptation is the deliberate and explicit manner in which it was achieved. The four cases exhibiting lack of microcongruence are also consistent with partial support for the culture-dominant view. Two of those cases (B and F) were attempting to use a hybrid marketing strategy making process that was different from that which had been historically prevalent in their organisation and had failed, as yet, to achieve the necessary adaptations to the organisational culture. The remaining two ( $\mathrm{K}$ and $\mathrm{R}$ ) both showed noticeable cultural heterogeneity or unevenness between headquarters and subsidiary cultures. Any process operating across an uneven culture might be expected, to some extent, to exhibit lack of microcongruence. Hence a consideration of the importance of microcongruence to strategy process would not support the view that fit between strategy process and culture is the dominant factor influencing the effectiveness of that process. It would, 
however, support the view that culture is likely to drive or mould strategy process unless deliberate steps are taken towards adaptation of culture.

\section{Proposition P4}

This fourth proposition, P4, would be consistent with the views of those who see external market contingencies as the dominant, perhaps overriding, factor in determining the effectiveness of marketing strategy making processes. Such a position minimises the importance of the internal, organisational culture, environment.

The findings neither uphold nor refute this proposition. Support or contradiction for proposition $\mathrm{P} 4$ would require the existence of cases which exhibited macrocongruence but not microcongruence. The existence of a strong strategy in such cases would provide support for P4. None of the 18 cases demonstrated macrocongruence without microcongruence, however. Such lack of positive evidence, however, does not contradict P4. Negative evidence is provided by those four cases (B, F, K and $\mathrm{R})$ which lacked macrocongruence and microcongruence and had weak strategies. This does not, however, constitute support for P4. Hence these findings, due to gaps in the sample, neither fully support nor entirely contradict this final proposition.

\section{Overall}

Taken as a whole, a consideration of the four propositions provides qualified support for the congruency hypotheses. In the same way, they support the combined congruency model that is the graphical expression of the hypotheses.

The findings are not entirely conclusive. It remains possible that only macrocongruence is significant in determining the effectiveness of hybrid marketing strategy making process. Since the findings provided positive and negative examples not only of macrocongruence but also of microcongruence it seems most likely, however, that mechanisms exist whereby both the external market environment and the internal cultural environment moderate the effectiveness of hybrid marketing strategy making process. Hence these findings support Burrell and Morgan's congruency hypotheses ${ }^{183}$ in the context of marketing strategy making. The slight qualification of this support can be explored and better understood by a consideration of the mechanism of microcongruence and macrocongruence suggested by these findings, and discussed in the third paper of this series.

\section{Discussion and implications for practitioners}

The work described in this second paper represents a useful synthesis of other researchers' work into a model which is then tested and found to be a valid explanation of why some marketing strategy processes succeed while others fail, resulting in a weak marketing strategy.

The primary conclusion suggested by this model is that no one approach to making marketing strategy is appropriate to all situations. This is an important and fundamental point. Business schools, consultants and trained practitioners almost always advocate a single model (that of rational planning) for the development of strong strategies. This work suggests that such an approach will only create a strong strategy in certain contexts of market conditions and organisational culture. For many if not most organisations, a marketing strategy making process that is not organisationally specific is likely to lead to a weak strategy. This implies that the organisation will fail to meet its business objectives unless it is in the fortunate situation of having weak competition or unusually favourable market conditions.

The further implication of this work is 
that, rather than adopt a generic marketing-strategy-making process, organisations would be better served to develop an organisationally tailored process. The more detailed findings of this work provide a framework for how this might be achieved in practice, and this is the subject of the third paper in this trilogy.

\section{(C) Brian Smith 2003}

\section{References}

1 Smith, B.D. (2003) 'An empirical investigation of marketing strategy quality in medical markets', International Journal of Medical Marketing, 3(2), 153-162.

2 Drucker, P.F. (1974) Management: Tasks, Responsibilities, Practices, 2nd edn. ButterworthHeinemann, Oxford.

3 Mintzberg, H. (2000) 'View from the top: Henry Mintzberg on strategy and management', Academy of Management Review, 14(3), 31-42.

4 Bailey, A., Johnson, G. and Daniels, K. (2000) 'Validation of a multi-dimensional measure of strategy development processes', The British Journal of Management, 11(2), 151-162.

5 Bennis, W. and Nanus, B. (1985) Leaders: The Strategies for Taking Charge. Harper \& Row, New York.

6 Shrivastava, P. and Grant, J.H. (1985) 'Empirically derived models of strategic decision making', Strategic Management Journal, 6(2), 97-113.

7 Westley, F. and Mintzberg, H. (1989) 'Visionary leadership and strategic management', Strategic Management Journal, 10, 17-32.

8 Kotter, J.P. (1990) A Force for Change: How Leadership Differs from Management. Free Press, New York.

9 Ansoff, I.H. (1965) Corporate Strategy. Penguin, London.

10 Mintzberg, H. (1978) 'Patterns of strategy formation', Management Science, 24(9), 934-948.

11 Steiner, G.A. (1969) Top Management Planning. MacMillan, New York

12 Argenti, J. (1980) Practical Corporate Planning. George Allen and Unwin, London.

13 Rowe, A.J, Dickel, K.E., Mason, R.O. and Snyder, N.H. (1989) Strategic Management: A Methodological Approach, 3rd edn. Addison-Wesley, New York.

14 Lindblom, C.E. (1959) 'The science of muddling through', Public Administration Review, 19(2), 79-88.

15 Mintzberg, H., Raisinghani, D. and Theoret, A (1976) 'The structure of unstructured decision making processes', Administrative Science Quarterly, 21(2), 246275.

16 Quinn, J.B. (1980) Strategies for Change: Logical Incrementalism. Irwin, Homewood, Illinois.

17 Johnson, G. (1988) 'Rethinking incrementalism', Strategic Management Journal, 9(1), 75-91.
18 Cyert, R.B. and March, J.G. (1963) A Behavioural Theory of the Firm. Prentice-Hall, Englewood Cliffs, New Jersey.

19 Pettigrew, A.M. (1973) The Politics of Organisational Decision Making. Tavistock Publications, London.

20 Hinings, C.R., Hickson, D.J., Pennings, J.M. and Schneck, R.E. (1974) 'Structural conditions of intraorganizational power', Administrative Science Quarterly, 19(1), 22-44.

21 Hickson, D.J., Butler, R., Cray, D., Mallory, G. and Wilson, D. (1986) Top Decisions: Strategic Decision Making in Organisations. Jossey-Bass, San Francisco, California.

22 Anderson, P.F. (1982) 'Marketing, strategic planning, and the theory of the firm', Journal of Marketing, 46(2), 15-26.

23 Weick, K.E. (1985) 'The significance of organisational culture', in Frost, P.J. (ed.), Organisational Culture. Sage Publications, Beverly Hills, California, 381-389.

24 Deal, T.E. and Kennedy, A.A. (1982) Corporate Cultures: The Rites and Rituals of Corporate Life, 1st edn. Addison-Wesley, Reading, Massachusetts.

25 Schein, E.H. (1984) 'Coming to a new awareness of organisational culture', Sloan Management Review, 25(2), 316.

26 Johnson, G. (1987) Strategic Change and Management Process, Oxford, Blackwell.

27 Aldrich, H.E. (1979) Organisations and Environments. Prentice-Hall, Englewood Cliffs, New Jersey.

28 DiMaggio, P. and Powell, W. (1983) 'The iron cage revisited: Institutional isomorphism and collective rationality in organisational field', American Sociology Review, 48(2), 147-160.

29 Hannan, M.T. and Freeman, J.H. (1984) 'Structural inertia and organisational change', American Sociology Review, 49(2), 149-164.

30 Mintzberg, H., Ahlstrand, B. and Lampel, J. (1998) Strategy Safari, 1st edn. The Free Press, New York.

31 Chaffee, E.E. (1985) 'Three models of strategy', Academy of Management Review, 10(1), 89-98.

32 Shrivastava, P. and Grant, J.H. (1985) op. cit.

33 Hart, S.L. (1991) 'Intentionality and autonomy in the strategy making process: Modes, archetypes and firm process', Advances in Strategic Management, 7, 97127.

34 Bourgeois, I.J. and Brodwin, D. (1984) 'Strategic implementation: Five approaches to an elusive phenomenon', Strategic Management Journal, 5(3), 241264

35 Hart, S.L. (1992) 'An integrative framework for strategy making processes', Academy of Management Review, 17(2), 327-351.

36 Bailey, A. and Johnson, G. (1994) 'A framework for understanding strategy development'. Unpublished paper.

37 Chaffee, E.E. (1985) op. cit.

38 Shrivastava, P. and Grant, J.H. (1985) op. cit.

39 Hart, S.L. (1991) op. cit.

40 Hart, S.L. (1992) op. cit.

41 Bourgeois, I.J. and Brodwin D. (1984) op. cit.

42 Bailey, A. and Johnson, G. (1994) op. cit.

43 McDonald, M.H.B. (1996) 'Strategic marketing 
planning: Theory, practice, and research agendas', Journal of Marketing Management, 12, 5-27.

44 Hise, R.T. (1965) 'Have manufacturing firms adopted the marketing concept?', Journal of Marketing, 29(3), 912

45 McNamara, C.P. (1972) 'The present status of the marketing concept', Journal of Marketing, 36(1), 50-57.

46 Ames, B.C. (1970) 'Trappings versus substance in industrial marketing', Harvard Business Review, 48(4), 93-102.

47 Bell, L. and Emory, C.W. (1971) 'The faltering marketing concept', Journal of Marketing Management, 35(4), 37-42.

48 Martin, J. (1979) 'Business planning: The gap between theory and practice', Long Range Planning, 12(6), 210.

49 Zeithaml, V., Parasuraman, A. and Berry, L. (1985) 'Problems and strategies in service marketing', Journal of Marketing, 49(2), 33-46.

50 Martin, J. (1987) 'Marketing planning and the human element', Irish Marketing News, 2, 34-42.

51 Hooley, G.J., West, C.J. and Lynch, J.E. (1990) Marketing in the UK: A Survey of Current Practice and Performance, 1st edn. Institute of Marketing, Cookham, Berkshire.

52 McDonald, M.H.B. (1996) op. cit.

53 Martin, J. (1979) op. cit.

54 Walker, O.C. and Ruekert, R.W. (1987) 'Marketing's role in the implementation of business strategies: A critical review and conceptual framework', Journal of Marketing, 51(3), 15-33.

55 Carson, D. and Cromie, S. (1989) 'Marketing planning in small enterprises: A model and some empirical evidence', Journal of Marketing Management, 1(4), 3349.

56 Currens, M., Folkes, V. and Steckel, J. (1992) 'Explanations of succesful and unsuccesful marketing decisions: The decision maker's perspective', Journal of Marketing, 56(2), 1831.

57 McColl-Kennedy, J. and Keil, G. (1990) 'Marketing planning practices in Australia: A comparison across company types', Marketing Intelligence and Planning, 8(4), 229.

58 Mowen, J. and Gaeth, G. (1992) 'The evaluation stage in marketing decision making', Journal of the Academy of Marketing Science, 20(2), 177-187.

59 Abratt, R. and Bendixen, M. (1993) 'Marketing planning: An empirical analysis of practices in British companies', University of Melbourne Graduate School of Management Working Paper 4. Unpublished paper.

60 Eisenhardt, K.M. and Zbaracki, M.J. (1992) 'Strategic decision making', Strategic Management Journal, 13, 1737.

61 Rajagopalan, N., Rasheed, A.M.A. and Datta, D.K. (1993) 'Strategic decision processes: Critical review and future directions', Journal of Management, 19(2), 349384.

62 Smith, B. (1999) 'Strategic marketing planning in UK medical companies'. Unpublished paper.

63 Glaister, K.W. and Falshaw, J.R. (1999) 'Strategic planning: Still going strong', Long Range Planning, 32(1), 107-116.
64 Jenkins, M. and McDonald, M.H.B. (1997) 'Market segmentation: Organisational archetypes and research agenda', European Journal of Marketing, 31(1), 17-32.

65 Piercy, N.F. and Giles, W. (1989) 'Making SWOT analysis work', Marketing Intelligence and Planning, 7(5), 57.

66 Piercy, N.F. (1997) Market-led Strategic Change: Transforming the Process of Going to Market, 2nd edn. Butterworth Heinemann, Oxford.

67 Greenley, G.E. and Bayus, B.L. (1994) 'Marketing planning processes in UK and US companies', Journal of Strategic Marketing, 2(2), 140-154.

68 Buzzell, R.D. and Wiersema, F.D. (1981) 'Successful share-building strategies', Harvard Business Review, 59 , 135-144.

69 McColl-Kennedy, J. and Keil, G. (1990) op. cit.

70 Greenley, G.E. (1985) 'Marketing plan utilisation', Quarterly Review of Marketing, 10, 12-19.

71 Haspeslagh, P. (1982) 'Portfolio planning: Uses and limits', Harvard Business Review, 60, 58-73.

72 Hopkins, D.S. (1981) The Marketing Plan. The Conference Board, New York.

73 Hooley, G.J., West, C.J. and Lynch, J.E. (1981) Marketing in the UK. The Institute of Marketing, Maidenhead.

74 Reid, D.M. and Hinckley, I.C. (1989) 'Strategic planning: The cultural impact', Marketing Intelligence and Planning, 7(11/12), 4-12.

75 Ross, J.E. and Silverblatt, R. (1987) 'Developing the strategic plan', Industrial Marketing Management, 16, 103-108.

76 Verhage, B.J. and Waarts, E. (1988) 'Marketing planning for improved performance: A comparative analysis', International Marketing Review, 5(2), 20-30.

77 Wittink, D.R. and Cattin, P. (1989) 'Commercial use of conjoint analysis: An update', Journal of Marketing, 53, 91-96.

78 Wood, D.R.J. and LaForge, R.L. (1989) 'Lessons from strategic portfolio planning in large US banks', $S A M$ Advanced Management Journal, 51, 25-31.

79 Bonoma, T.V. (1985) The Marketing Edge: Making Strategies Work, 1st edn. The Free Press, New York.

80 Hutt, M.D., Reingen, P.H. and Ronchetto, J.R. (1988) 'Tracing emergent processes in marketing strategy formation', Journal of Marketing, 52(1), 4-19.

81 Kohli, A. and Jaworski, B.J. (1990) 'Market orientation: The construct, research propositions and managerial implications', Journal of Marketing, 54(2), 119.

82 Menon, A., Bharadwaj, S.G. and Howell, R. (1996) 'The quality and effectiveness of marketing strategy: Effects of functional and dysfunctional conflict in intraorganisational relationships', Journal of the Academy of Marketing Science, 24(4), 299-313.

83 Marketing Science Institute (1998) Research Priorities: A Guide to MSI Research Programmes and Procedures 19982000. Marketing Science Institute, Cambridge, Massachusetts.

84 Varadarajan, P.R. (1999) 'Strategy content and process perspectives revisited', Journal of the Academy of Marketing Science, 27(1), 88-100.

85 Sheth, J. and Sisodia, R.S. (1999) 'Revisiting 
marketing's lawlike generalisations', Journal of the Academy of Marketing Science, 27, 71-87.

86 Menon, A., Bharadwaj, S.G., Adidam, P.T. and Edison, S.W. (1999) 'Antecedants and consequences of marketing strategy making: A model and a test', Journal of Marketing, 63, 18-40.

87 Wong, V., Saunders, J. and Doyle, P. (1989) 'The barriers to achieving a stronger market orientation in British companies: An exploratory study', Department of Management Studies, Loughborough University.

88 McDonald, M.H.B. (1989) 'Ten barriers to marketing planning', Journal of Marketing Management, 5(1), 1-18.

89 McDonald, M.H.B. (1996) op. cit.

90 McDonald, M.H.B. and Wilson, H.N. (1999) 'Exploiting technique interrelationships: A model of strategic marketing planning', Journal of Euromarketing, 7(3), 1-26.

91 Stampfl, R.W. (1983) 'Structural analysis and the marketing concept: Problems and solutions', in P.R. Varadarajan (ed.), The Marketing Concept: Perspective and Viewpoints. The Marketing Department, Texas A\&M University, 95-107.

92 Ruekert, R.W. and Walker, O.C. (1987) 'Marketing's interaction with other functional units: A conceptual approach and empirical evidence', Journal of Marketing, 51(1), 1-19.

93 Ibid.

94 Lindsay, W.M. and Rue, L.W. (1980) 'Impact of the organization environment on the long range planning process: A contingency view', Academy of Management Journal, 23(3), 385-404.

95 Pearce, J.A. II, Robbins, D.K. and Robinson, R.B. 'The impact of grand strategy and planning formality on financial performance', Strategic Management Journal (1987), 8(2), 125-134.

96 McKiernan, P. and Morris, C. (1994) 'Strategic planning and financial performance in UK SMEs', British Journal of Management, 5, 531-541.

97 Bishop, R.C. and Bresser, R.K. (1983) 'Dysfunctional effects of formal planning: Two theoretical explanations', Academy of Management Review, 8(4), 588-599.

98 Ruekert, R.W. (1992) 'Developing market orientation: An organizational strategy perspective', International Journal of Research in Marketing, 9(3), 225245.

99 Liu, H. (1995) 'Market orientation and firm size: An empirical examination in UK firms', European Journal of Marketing, 29(1), 57-71.

100 Lancaster, G. and Waddelow, I. (1998) 'An empirical investigation into the process of strategic marketing planning in SMEs: Its attendant problems, and proposals towards a new practical paradigm', Journal of Marketing Management, 14(8), 853-878.

101 Marginson, D.E.W. (2002) 'Management control systems and their effects on strategy formation at middle-management levels: Evidence from a UK organisation', Strategic Management Journal, 23, 10191031.

102 Liu, H. (1995) op. cit.

103 Lancaster, G. and Waddelow, I. (1998) op. cit.

104 Hendry, J. (2000) 'Strategic decision making, discourse and strategy as social practice', Journal of Management Studies, 37(7), 955-977.

105 Hendry, J. and Seidl, D. (2003) 'The structure and significance of strategic episodes: Social systems theory and the routine practices of strategic change', Journal of Management Studies, 40(1), 175-197.

106 Maitlis, S. and Lawrence, T.B. (2003) 'Orchestral manoeuvres in the dark: Understanding failure in organisational strategizing', Journal of Management Studies, 40(1), 109-139.

107 Harris, L.C. (1999) 'Initiating planning: The problem of entrenched cultural values', Long Range Planning, 32(1), 117-126.

108 Harris, L.C. and Ogbonna, E. (1999) 'Developing a market oriented culture: A critical evaluation', Journal of Management Studies, 36(2), 177-196.

109 Harris, L.C. (1999) 'Management behavior and barriers to market orientation in retailing companies', Journal of Services Marketing, 13(2), 113-131.

110 Harris, L.C. (1996) 'The anti-planner's tactics to thwart planning initiation', Journal of Strategic Marketing, 4(4), 239-253.

111 Harris, L.C. and Ogbonna, E. (1999) 'The strategic legacy of company founders', Long Range Planning, 32(3), 333-343.

112 Harris, L.C. (1999) 'A contingency approach to market orientation: distinguishing behaviours, systems, structures, strategies, and performance characteristics', Journal of Marketing Management, 15(7), 617-646.

113 Harris, L.C. and Ogbonna, E. (2001) 'Strategic human resource management, market orientation, and organizational performance', Journal of Business Research, 51(2), 157-166.

114 Harris, L.C. (2000) 'Getting professionals to plan: Pressures, obstacles and tactical responses', Long Range Planning, 33(6), 849-877.

115 Harris, L.C. (1999) op. cit.

116 Tagiuri, R. and Litwin, G. (1968) Organizational Climate: Explorations of a Concept. Harvard Business School, Boston.

117 Denison, D.R. (1996) 'What is the difference between organizational culture and organizational climate? A native's point of view on a decade of paradigm wars', Academy of Management Review, 21(3), 619-654.

118 Denison, D.R. (1984) 'Bringing corporate culture to the bottom line', Organizational Dynamics, 13(2), 4-22.

119 Denison, D.R. (1990) Corporate Culture and Organizational Effectiveness, 1st edn. Wiley, New York

120 Kotter, J.P. and Heskett, J.L. (1992) Corporate Culture and Performance, 1st edn. Free Press, New York.

121 Denison, D.R. and Mishra, A.K. (1995) 'Towards a theory of organisational culture and effectiveness', Organizational Science, 6(2), 204-221.

122 Pettigrew, A.M. (1979) 'On studying organizational cultures', Administrative Science Quarterly, 24(4), 570581.

123 Martin, J. (1992) Cultures in Organizations: Three Perspectives, 1st edn. Oxford University Press, New York.

124 Smirchich, L. (1983) 'Concepts of culture and organizational analysis', Administrative Science Quarterly, 28(3), 339-358. 
125 Wilkins, A.L. and Ouchi, W.G. (1983) 'Efficient cultures: Exploring the relationship between culture and organisational performance', Administrative Science Quarterly, 28(3), 468-481.

126 Schein, E.H. (1984) op. cit.

127 Schein, E.H. (1991) 'What is culture?', in P.J. Frost, L.F. Moore, M.R. Louis, C.C. Lundberg and J. Martin (eds), Reframing Organizational Culture. Sage, Newbury Park, California, 243-253.

128 Drucker, P.F. (1993) 'Corporate culture: Use it, don't lose it', in P.F. Drucker (ed.), Managing for the Future. Butterworth Heinemann, Oxford, 150-154.

129 Fitzgerald, T.H. (1988) 'Can change in organisational culture really be managed?', Organizational Dynamics, 17(2), 5-15.

130 Ogbonna, E. (1993) 'Managing organisational culture: Fantasy or reality?', Human Resource Management Journal, 3(2), 42-54.

131 Legge, K. (1994) 'Managing culture: Fact or fiction', in K. Sissons (ed.), Personnel Management: $A$ Comprehensive Guide to Theory and Practice in Britain. Blackwell, Oxford, 397-432.

132 Ibid.

133 Ogbonna, E. (1993) op. cit.

134 Hatch, M.J. (1999) 'The cultural dynamics of organisational change', in N.M. Ashkanasy, C. Wilderom and M.F. Peterson (eds), The Handbook of Organizational Culture and Climate. Sage, Thousand Oaks, California.

135 Lorsch, J.W. (1986) 'Managing culture: The invisible barrier to strategic change', California Management Review, 28(2), 95-109.

136 Drucker, P.F. (1993) op. cit.

137 Wilkins, A.L. and Ouchi, W.G. (1983) op. cit.

138 Harris, L.C. and Ogbonna, E. (2002) 'The unintended consequences of culture interventions: A study of unexpected outcomes', British Journal of Management, 13, 31-49.

139 Deshpande, R. and Webster, F.W. (1989) 'Organizational culture and marketing: Defining the research agenda', Journal of Marketing, 53(1), 3-15.

140 Saker, J. and Speed, R. (1992) 'Corporate culture: Is it really a barrier to marketing planning?', Journal of Marketing Management, 8(2), 177-181.

141 Cespedes, F.V. and Piercy, N.F. (1996) 'Implementing marketing strategy', Journal of Marketing Management, 12, 135-160.

142 Saker, J., Speed R. (1992) op. cit.

143 Nadler, D.A. and Tushman, M.L. (1980) 'A congruence model for organizational assessment', in E.E. Lawler, D.A. Nadler and C. Camman (eds), Organizational Assessment: Perspectives on the Management of Organizational Behaviour and the Quality of Working Life. Wiley, New York, 261-278.

144 Schwartz, H. and Davis, S.M. (1981) 'Matching corporate culture and business strategy', Organizational Dynamics, 10(1), 30-48.

145 Hofstede, G. (1984) 'Cultural dimensions in management and planning', Asia Pacific Journal of Management, 1(1), 81-99.

146 Pearce, J.A. II and Randolph, A.W. (1980) 'Improving strategy formulation pedagogies by recognizing behavioral aspects', Exchange: The Organizational Behavior Teaching Journal, 5(4), 7-9.

147 Schwartz, H. and Davis, S.M. (1981) op. cit. 148 Peters, T. and Waterman, R. (1982) In Search of Excellence, 1st edn. Harpers \& Row, New York.

149 Deal, T.E. and Kennedy, A.A. (1982) op. cit.

150 Dunn, M.G., Norburn, D. and Birley, S. (1994) 'The impact of organisational values, goals and climate on marketing effectiveness', Journal of Business Research, 30(2), 131-141.

151 Dobni, C.B. and Luffman, G. (2000) 'Implementing marketing strategy through a market orientation', Journal of Marketing Management, 16(8), 895-916.

152 Pulendran, S. and Speed, R. (1996) 'Planning and doing: The relationship between marketing planning styles and market orientation', Journal of Marketing Management, 12(13), 53-68.

153 Day, G.S. (1994) 'The capabilities of market-driven organizations', Journal of Marketing, 58, 37-52.

154 Deshpande, R. and Webster, F.W. (1989) op. cit.

155 Liu, H. (1995) op. cit.

156 Narver, J.C. and Slater, S. (1990) 'The effect of market orientation on business profitability', Journal of Marketing, 54, 20-35.

157 Legge K. (1994) op. cit.

158 Harris, L.C. and Ogbonna, E. (2002) op. cit.

159 Tadepalli, R. and Avila, R.A. (1999) 'Marketing orientation and the marketing strategy process', Journal of Marketing, 7(2), 69-82.

160 McDonald, M.H.B. (1982) 'Theory and practice of marketing planning for industrial goods in international markets', Cranfield University School of Management.

161 Bishop, R.C. and Bresser, R.K. (1983) op. cit.

162 Eisenhardt, K.M. (1989) 'Making fast strategic decisions in high-velocity environments', Academy of Management Journal, 32(3), 543-576.

163 Eisenhardt, K.M. (1999) 'Strategy as strategic decision making', Sloan Management Review, 40(3), 65-72.

164 Eisenhardt, K.M. and Sull, D.N. (2001) 'Strategy as simple rules', Harvard Business Review, 79(1), 106-116.

165 Fredrickson, J.R. (1984) 'The comprehensiveness of strategic decision processes: Extension, observations, future directions', Academy of Management Journal, 27(3), 445-466.

166 Fredrickson, J.R. and Mitchell, T.R. (1984) 'Strategic decision processes, comprehensiveness and performance in an industry with an unstable environment', Academy of Management Journal, 27(3), 399-423.

167 Pelham, A.M. (1999) 'Influence of environment, strategy and market orientation on performance in small manufacturing firms', Journal of Business Research, 45(1), 33-46.

168 Speed, R. (1994) 'Environmental context and marketing planning processes', Journal of Marketing Management, 10(7), 667-677.

169 Pulendran, S. and Speed R. (1996) op. cit.

170 Slevin, D.P. and Covin, J.G. (1997) 'Strategy formation patterns, performance and the significance of context', Journal of Management, 32(2), 189-209. 
171 Mintzberg, H. (1990) 'The design school: Reconsidering the basic premises of strategic management', Strategic Management Journal, 11(3), 171195.

172 Ansoff, I.H. (1991) ‘Critique of Henry Mintzberg's "The design school: Reconsidering the basic premises of strategic management"', Strategic Management Journal, 12(6), 449-461.

173 Thompson, J.D. (1967) Organisations in Action, 1st edn. McGraw Hill, New York.

174 Zeithaml, V., Varadarajan P.R. and Zeithaml C.P. (1988) 'The contingency approach: Its foundations and relevance to theory building and research in marketing', European Journal of Marketing, 22(7), 35-64.

175 Harrigan, K.R. (1983) 'Research methodologies for contingency approaches to business strategy', Academy of Management Review, 8(3), 398-405.

176 Hambrick, D.C. (1983) 'An empirical typology of mature industrial-product environments', Academy of Management Journal, 26(2), 213-30.

177 Lawrence, P.R. and Lorsch, J.W. (1967)

'Differentiation and integration in complex organisations', Administrative Science Quarterly, 12(1), $1-47$.

178 Burrell, G. and Morgan, G. (1979) 'Sociological paradigms and organizational analysis', 1st edn. Sage, Beverley Hills, California.

179 Morgan, G. (1986) Images of Organization. Sage, Beverley Hills, California.

180 Easterby-Smith, M., Thorpe, R. and Lowe, A. (1995) Management Research: An Introduction. Sage, London.

181 Smith, B.D. (2003) op. cit.

182 Smith, B.D. (2003) 'The effectiveness of marketing strategy making processes in medical markets', Cranfield School of Management.

183 Burrell, G. and Morgan G. (1979) op. cit. 
Copyright $\odot 2003$ EBSCO Publishing 